\title{
Investigation of the Roof Presplitting and Rock Mass Filling Approach on Controlling Large Deformations and Coal Bumps in Deep High-
}

\section{Stress Roadways}

\author{
Fuzhou Qia,b \\ Zhanguo $\mathrm{Ma}^{\mathrm{a}, \mathrm{b} *}$ \\ a State Key Laboratory for Geomechanics and Deep Underground Engineering, China University of Mining and Technology, Xuzhou 221116, \\ China. E-mail: 18255416386@163.com, 1044@cumt.edu.cn \\ b School of Mechanics and Civil Engineering, China University of Mining and Technology, Xuzhou 221116, China.
}

${ }^{*}$ Corresponding author

http://dx.doi.org/10.1590/1679-78255586

\begin{abstract}
Roadway deformation and coal bumps are major challenges for underground engineering. Taking the Lu'an mining district in Shanxi Province as an example, the failure mechanism of deep high-stress roadway was studied. Numerical simulations and the similar material test were performed to investigate the effect of the roof presplitting and rock mass filling on the stability of roadway surrounding rock. The change laws and distribution features of stress and plastic zone, and the fracture characteristics of roof strata were analyzed. Under conditions where the roof was not presplit, the roadway was in a high-stress environment due to the massive suspended roof. The failure process of the high-stress roadway began with tensile crack in the shallow roof and then extended to the two ribs, resulting in the yield of a coal pillar. Under the condition that the roof was presplit, the peak value of the vertical stress at the coal pillar was decreased from 18.2 to $9.8 \mathrm{MPa}$ while that of the virgin coal rib was decreased from 15.8 to $13.5 \mathrm{MPa}$. Both the similar material test and numerical results showed that the Roof outside the Coal Pillar (RCP) was cut off along the presplitting lines and was fractured into different sizes of masses. The broken rock mass filled in the goaf and supported on the overlying strata, which reduced the load on the coal pillar. The field monitoring data indicated that implementing the roof presplitting and rock mass filling processes successfully controlled large deformations of the roadway and coal bumps, which improved the stability of surrounding rock.
\end{abstract}

\section{Keywords}

Massive suspended roof; roof presplitting; rock mass filling; similar material test; stress transfer 


\section{INTRODUCTION}

With the depletion of shallow resources, the deep mining stage of coal resources has gradually arrived (Kang 2014, Yang et al. 2017). Unlike the shallow mining case, the surrounding rock of the deep roadway shows high stress, large deformation and coal bump (Xie et al. 2015, Chen et al. 2016). Moreover, a series of problems concerning the stability of the roadway emerge, such as roof separation and sagging, rib shrinkage and coal bumps. The failure of roadway functions can seriously affect both the mining production and the safety of miners. Therefore, great importance has been attached to the study of the deformation, stress and stability of the deep high-stress roadway. Numerous methods have been adopted to investigate the failure process and stability mechanism of roadway surrounding rock, including theoretical analysis (Cohen et al. 2009, Tang and Kung 2009, Qin et al. 2015), numerical simulation, similar material test and field test (Read 2004, Shen et al. 2008, Yu et al. 2016).

The similar material test has become an effective method to analyse the failure process of a roadway. Based on infrared imaging, He et al. (2010) and He (2011) studied the damaged characteristics of roadway excavation when the angle of the inclined coal seam varied. Zhu et al. (2011) investigated the failure mechanism of the high-stress roadway via a physical model test; the results showed that as the stress to rock-strength ratios increased to greater than 1.5, roadway roof and ribs displacements occurred. Through the similar material test, Huang et al. (2013) studied the influence of a weak interlayer of the rock mass on the roadway failure pattern and found that the important factors making the roadway unstable were the position and thickness of the interlayer and the distance between the interlayer and the roadway. By conducting a large-scale geological model test, Li et al. (2015) investigated the deformation law of the roadway surrounding rock and proposed an anchor box beam system supporting system to control the deformation. Liu et al. (2017) adopted a model test to study the stress distribution law of tunnel in bedding rock mass with asymmetrical loading.

Recently, because of its low cost and good repeatability, numerical simulation is increasingly being developed and used to investigate the stability of the roadway. Pellet et al. (2009) implemented numerical study to analyse the development of damage zone during roadway excavation. Zhang et al. (2012) evaluated the effects of the stratified rock structure on failure pattern around tunnel. Shen (2014) analysed the failure mechanism of a high-stress roadway in soft rock via Universal Distinct Element Code (UDEC). Gao et al. (2015) applied UDEC to simulate squeezing failure process and realistically captured the intrinsic discontinuous damage and deformation. Considering the role of fractures within rock mass, Karampinos et al. (2015) employed the distinct element method (3DEC) to investigate the Bending failure of roadway in deep hard rock mines. Li \& Weng (2016) investigated the fracturing behaviour of an underground opening caused by dynamic disturbance; the results showed that the lateral pressure coefficient (horizontal and vertical stress ratio) was the major cause of roadway instability.

After reviewing numerous previous studies, we find that because of the differences in both geological conditions and lithologic characteristics of underground engineering projects, the failure mechanism of the deep high-stress roadway remains unclear. The approach of roof presplitting and rock mass filling is presented in this study, from different perspectives, to relieve stress concentration and maintain the stability of surrounding rock. In the process, roof presplitting was used to break off the roof strata connection of the roadway and the goaf, thus adjusting the roadway stress environment. Moreover, by means of the bulking characteristics of the broken rock mass in the goaf, a stable bearing structure was formed to support the upper strata that could alleviate the load on both coal ribs of the roadway. To better understand stability control mechanism for high-stress roadways, a numerical model was created to investigate the fracture characteristics of the roof outside the coal pillar (RCP), the stress variation and the plastic zone distribution of the surrounding rock. With the assistance of an advanced multi-point grating extensometer monitoring system and a stress acquisition system, a similar test was then built to obtain data for comparison with the results of the numerical 
simulation. The proposed novel approach to improve the stability of the roadway was successfully implemented in a field application, which also could be used in other similar mines.

\section{ENGINEERING BACKGROUND OF THE STUDY AREA}

\subsection{Geological conditions of engineering}

The lu'an mining district is located in Changzhi City, Shanxi Province, China. Figure 1 shows the layout of panels 8101,8102 , and 8103 for the deep coal mine. The strike and dip length of panels are $1560 \mathrm{~m}$ and $210 \mathrm{~m}$, respectively. The buried depth of the coal seams is nearly $300 \mathrm{~m}$, and their average thickness is $4 \mathrm{~m}$. The 8102 headgate (Figure 1) is excavated along the coal seam floor, with a $5 \mathrm{~m}$ width and $3.5 \mathrm{~m}$ height. The upper strata of the roadway include, in order, mudstone, siltstone, and sandy mudstone, and the lower strata include, in order, mudstone, fine sandstone and siltstone. The lithology is shown in Figure 2. During the panel retreat, severe deformation and coal bumps occurred frequently on the 8102 headgate (Figure 3), which seriously threatened the lives of coal mine workers. The field data indicated that the maximum deformations of the roof, virgin coal rib, coal pillar rib, and floor were $920,384,635$, and $145 \mathrm{~mm}$, respectively. Therefore, the 8102 headgate was selected as the object of study to understand the deformation failure of the deep high-stress roadway.

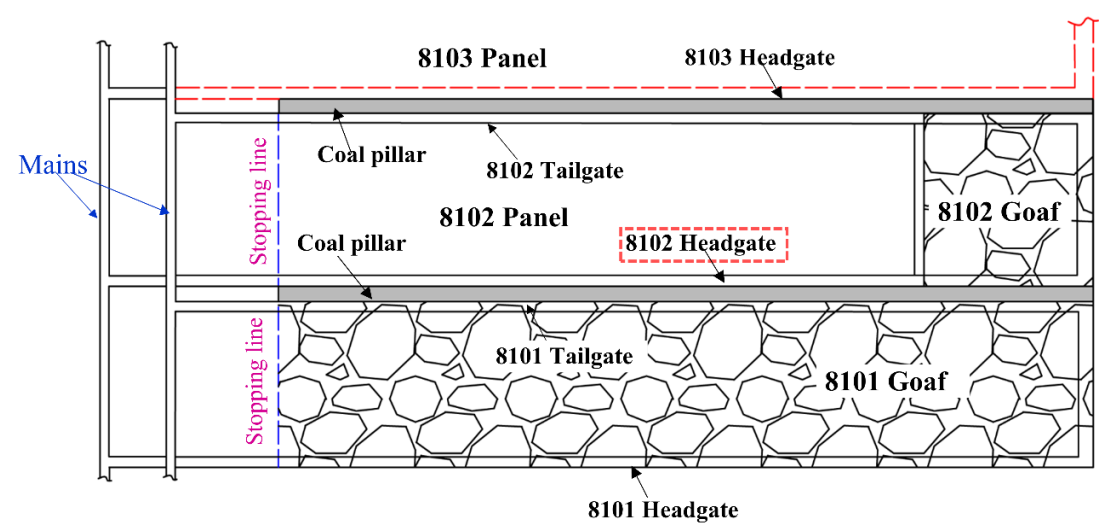

Figure 1: Layout of the panels and the roadway.

\begin{tabular}{|c|c|c|c|}
\hline Lithology & $\begin{array}{l}\text { Thickness } \\
\text { (m) }\end{array}$ & $\begin{array}{c}\text { Cover depth } \\
(\mathrm{m})\end{array}$ & Remarks \\
\hline Fine sandstone & 5.4 & 5.4 & \\
\hline Mudstone & 9.6 & 5.4 & \\
\hline Sandy mudstone & 6.4 & 5.4 & \\
\hline Siltstone & 7.8 & 5.4 & Main Roof \\
\hline Mudstone & 3.6 & 5.4 & Immediate Roof \\
\hline Coal seam & 4.0 & 5.4 & Coal \\
\hline Mudstone & 4.2 & 5.4 & Immediate Floor \\
\hline Fine sandstone & 6.4 & 5.4 & Main Floor \\
\hline Siltstone & 4.5 & 5.4 & \\
\hline
\end{tabular}

Figure 2: The detailed stratigraphic column. 


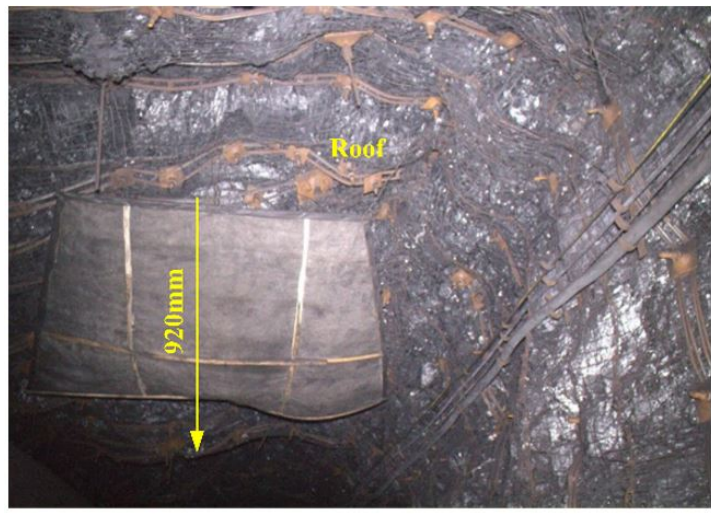

(a) Roof sagging

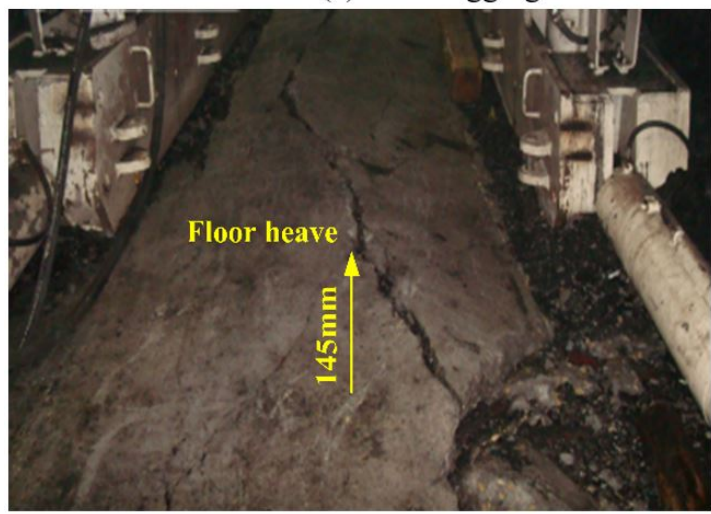

(c) Floor heave

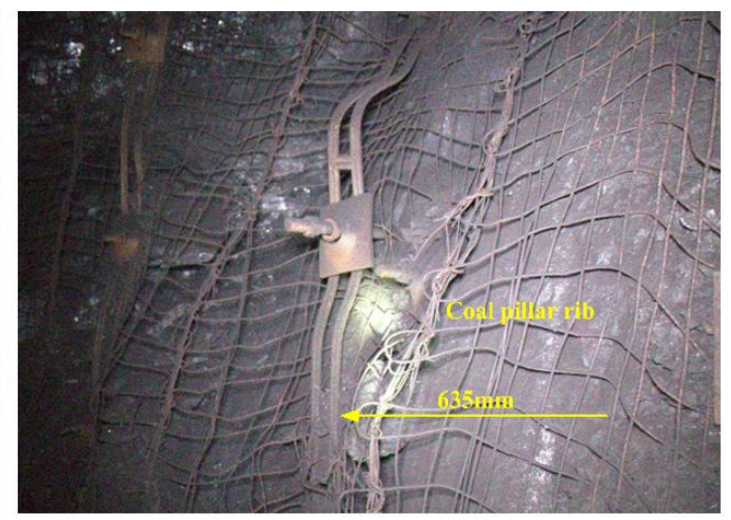

(b) Sides shrinking

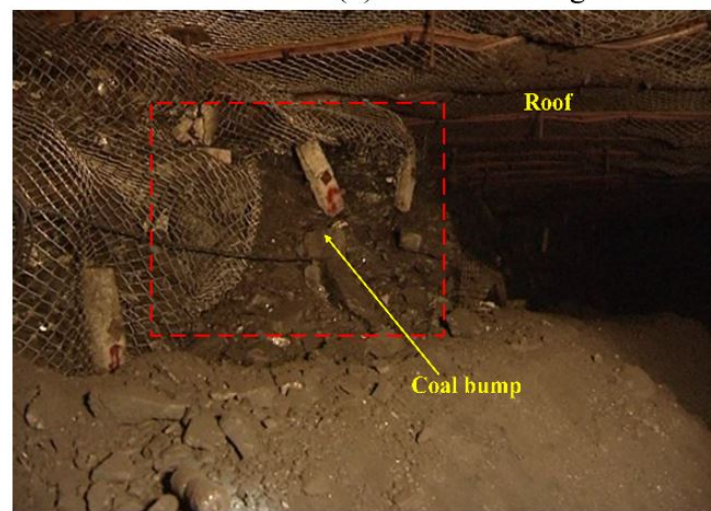

(d) Coal bump

Figure 3: Severe deformation of the 8102 headgate during panel retreat.

\subsection{A novel approach to improve roadway stability}

As shown in Figure 4, the RCP breaks and rotates towards the goaf after the adjacent panel retreat for conventional roadway excavation. The coal pillar bears almost all the loads of roof strata. The stability of roadway is greatly influenced by roof rotation and subsidence. The roadway is prone to large deformation and coal bumps. Unlike the excavation design of conventional roadways, the novel design approach of improving roadway stability includes two stages, as shown in Figure 5: the roof presplitting stage and rock mass filling stage. At the roof presplitting stage, a roof presplitting line is set in the roadway of the previous panel in advance (Figure 5a). This line can break off the strata connection between roofs and prevent stress transfer between the design roadway and the adjacent panel. At the rock mass filling stage, with the adjacent panel retreat, roof strata collapse occurs along the presplitting line and fractures into different shapes of masses, as shown in Figure $5 \mathrm{~b}$. The collapsed rock mass forms a stable bearing structure and supports the overlying strata. The strata load on the roof of the design roadway is borne by three parts: a virgin coal rib, coal pillar rib and collapsed rock mass. The manual and natural rock masses can be used together to optimize the stress conditions of the surrounding rock and to improve the stability of the roadway. 


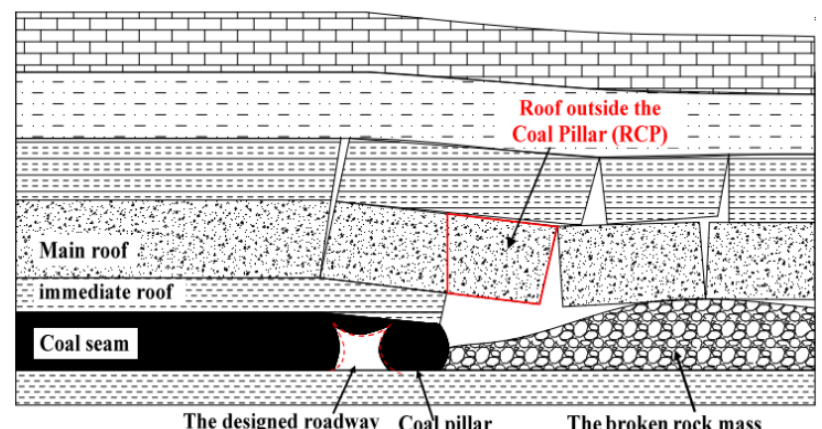

Figure 4: The conventional roadway excavation design.

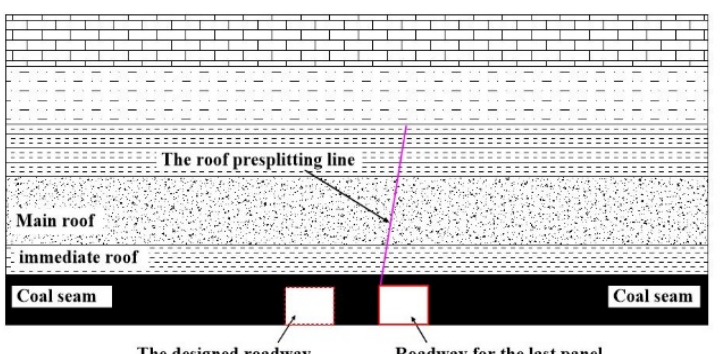

The designed roadway
Roadway for the last panel

(a) Roof presplitting stage

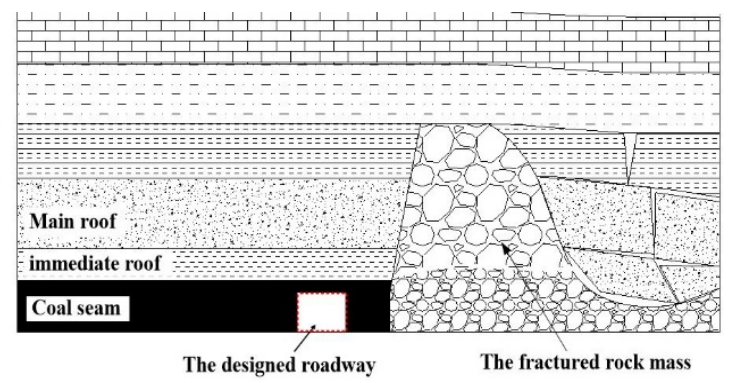

(b) Rock mass filling stage

Figure 5:Roadway design approach.

\subsection{Roof presplitting height}

With retreat of the adjacent panel, RCP is cut off along the presplitting line. The collapsed rock are compacted to mitigate the stress concentration in coal pillars because the partial vertical load will be undertaken by the broken rock in goaf (Yavuz 2004, Shabanimashcool and Li 2013). Hence, it is essential to study the RCP presplitting height when the supporting effect of the collapsed rock mass is considered.

After the rock strata collapse, the volume of the broken rock mass increases and the piling height is greater than the height of original rock strata. The volume expansion of the rock mass entirely depends on the bulking coefficient $K_{\mathrm{p}}$ which determines the piling height of the broken rock mass. If the initial height of rock strata is $\Sigma h$, and the piling height of broken rock strata is $K_{p} \Sigma h$, then the possible clearance height between the piled rock strata and the overlying stable rock strata will be:

$$
\Delta=\sum \mathrm{h}+\mathrm{M}-\mathrm{K}_{\mathrm{p}} \sum \mathrm{h}=\mathrm{M}-\sum \mathrm{h}\left(\mathrm{K}_{\mathrm{p}}-1\right)
$$

where $\Delta$ is the clearance height between the piled rock strata and the overlying stable rock strata; $\Sigma h$ is the initial height of rock strata; $M$ is the height of coal seam; $K_{p} \Sigma h$ is the piling height of the broken rock strata; and $K_{p}$ is the bulking coefficient.

If $\Delta=0$, that is, the collapsed materials fill the whole goaf and support the load of the overlying rock strata (Whittles et al. 2006, Peng 2006), then:

$$
\sum \mathrm{h}=\frac{\mathrm{M}}{\mathrm{K}_{\mathrm{p}}-1}
$$


For the 8102 panel, the coal seam mining height is $4 \mathrm{~m}$ and the bulking coefficient is estimated to be 1.25 ; thus, the roof presplitting height is $16 \mathrm{~m}$.

\section{MODEL ESTABLISHMENT AND SIMULATION RESULTS}

\subsection{Introduction of UDEC software}

The UDEC is suitable for the analysis of the nonlinear mechanical behavior of rock mass through simulations of the motion, fracture, and diastrophism of the rock mass (Itasca Consulting Group Inc 2008). Therefore, a numerical model is established to investigate the movement characteristics of roof strata using the UDEC software. In the UDEC model, rock is represented by the assembly of blocks hinged to each other through the contacts.

During the modelling, the Coulomb law of friction is used for the contact to simulate the sliding or opening between rock strata. The normal contact is determined by the normal stiffness $\left(k_{n}\right)$ and stress-displacement is represented by the following equation:

$\Delta \sigma_{\mathrm{n}}=-\mathrm{k}_{\mathrm{n}} \Delta \mathrm{u}_{\mathrm{n}}$

where $\Delta \sigma_{\mathrm{n}}$ and $\Delta \mathrm{u}_{\mathrm{n}}$ are the stress variable and the displacement variable, respectively. For the contact, if the stress exceeds the tensile strength, then $\sigma_{\mathrm{n}}=0$.

The tangential contact is dominated by the shear stiffness $\left(k_{\mathrm{s}}\right)$ and the shear strength $\left(\tau_{\max }\right)$. The shear strength $\tau_{\mathrm{s}}$ is jointly determined by cohesion $(c)$ and friction angle $(\phi)$.

If

$\left|\tau_{\mathrm{s}}\right| \leq \mathrm{c}+\sigma_{\mathrm{n}} \tan \phi=\tau_{\max }$

Then

$\Delta \tau_{\mathrm{s}}=\mathrm{k}_{\mathrm{s}} \Delta \mathrm{u}_{\mathrm{s}}^{\mathrm{e}}$

Or else, if

$\left|\tau_{\mathrm{s}}\right| \geq \tau_{\max }$

Then

$\tau_{\mathrm{s}}=\operatorname{sign}\left(\Delta \mathrm{u}_{\mathrm{s}}\right) \tau_{\max }$

where $\Delta \mathrm{u}_{\mathrm{e}}^{\mathrm{s}}$ is the elastic variable of shear deformation, and $\Delta \mathrm{u}_{\mathrm{s}}$ is the sum of the shear deformation .

\subsection{Validation of the rock mass property for the UDEC model}

Because of the joints and fractures in the rock mass, the engineering rock strength is lower than that of the rock specimens obtained from laboratory tests. Therefore, it is quite necessary to convert the strength of the rock specimens 
into the engineering rock strength. Based on the surface features of rock mass, Hoek et al. (1998) and Marinos and Hoek (2000) adopted GSI (Geological Strength Index) to build the strength relationship between the rock specimens and the engineering rock mass. The surface feature parameters of rock mass, such as $m_{b}, s$ and $a$, were calculated by the following equations (Hoek et al. 2002):

$\mathrm{m}_{\mathrm{b}}=\mathrm{m}_{\mathrm{i}} \exp \left(\frac{\mathrm{GSI}-100}{28-14 \mathrm{D}}\right)$

$\mathrm{s}=\exp \left(\frac{\mathrm{GSI}-100}{9-3 \mathrm{D}}\right)$

$\mathrm{a}=\frac{1}{2}+\frac{1}{6}\left(\mathrm{e}^{-\frac{\mathrm{GSI}}{15}}-\mathrm{e}^{-\frac{20}{3}}\right)$

where $D$ is the parameter related to rock integrity. According to (Hoek et al. 2002), the parameter $D$ is set to 0.5 based on the geological conditions.

From equations (11) and (12), the strength properties of the engineering rock mass can be obtained. Table 1 shows the detailed results between the rock specimens and the engineering rock mass.

$\mathrm{E}_{\mathrm{m}}=\left(1-\frac{\mathrm{D}}{2}\right) \sqrt{\frac{\sigma_{\mathrm{ci}}}{100}} \cdot 10^{\frac{\mathrm{GSI}-10}{40}}$

$\sigma_{c}=\sigma_{c i} \frac{\left(m_{b}+4 s-a\left(m_{b}-8 s\right)\right)\left(\frac{m_{b}}{4+s}\right)^{a s-1}}{2(1+a)(2+a)}$

Table 1: The corresponding parameters between rock specimens and the engineering rock mass.

\begin{tabular}{|c|c|c|c|c|c|c|c|c|c|}
\hline \multirow{2}{*}{ Lithology } & \multicolumn{2}{|c|}{ Rock specimens } & \multicolumn{3}{|c|}{ Constant } & \multicolumn{2}{|r|}{ GSI } & \multicolumn{2}{|c|}{ Rock mass } \\
\hline & $\sigma_{c i} / \mathrm{MPa}$ & $\mu$ & $s$ & $a$ & $m_{b}$ & $m_{i}$ & & $\sigma_{c} / \mathrm{MPa}$ & $E_{m} / \mathrm{GPa}$ \\
\hline Fine sandstone & 58.5 & 0.22 & 0.00066 & 0.50809 & 1.31045 & 18 & 55 & 15.7 & 4.3 \\
\hline Sandy mudstone & 28.3 & 0.26 & 0.00022 & 0.51389 & 0.44808 & 9 & 46 & 7.3 & 1.9 \\
\hline Siltstone & 48.2 & 0.23 & 0.00038 & 0.51062 & 0.7228 & 12 & 50 & 12.6 & 3.1 \\
\hline Mudstone & 13.5 & 0.29 & 0.00017 & 0.51595 & 0.31685 & 7 & 43 & 3.5 & 1.2 \\
\hline Coal seam & 10.1 & 0.32 & 0.00010 & 0.52089 & 0.2980 & 8 & 39 & 2.5 & 0.8 \\
\hline
\end{tabular}

Note:GSI is geological strength index.

The microproperties of the block contacts were obtained by simulating a large number of uniaxial compression specimens (Figure 6). The simulated uniaxial compression specimens were repeatedly checked until the simulation results matched with the elasticity modulus and compressive strengths of the engineering rock mass (Yang et al. 2017, Zhang et al. 2018). Table 2 shows the rock mechanical properties in the UDEC model. 


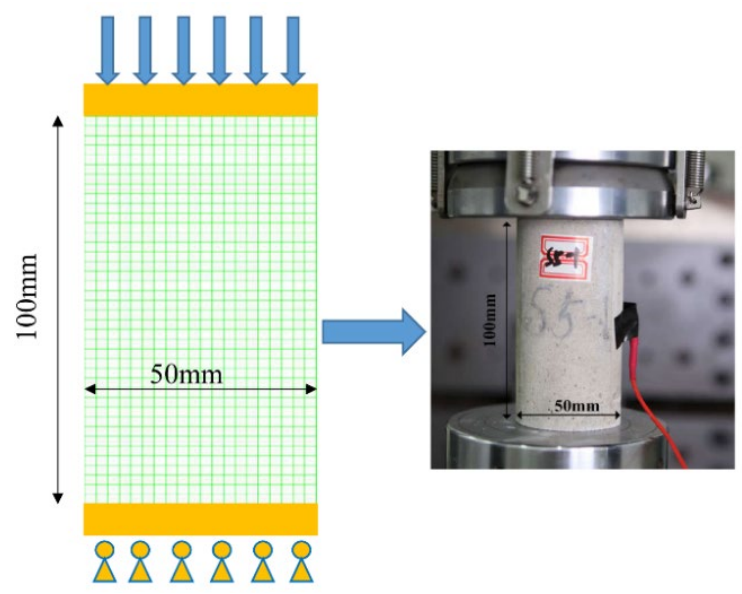

Figure 6:The simulated uniaxial compression specimens.

Table 2: The rock mechanical properties in the Universal Distinct Element Code UDEC model.

\begin{tabular}{|c|c|c|c|c|c|c|c|c|c|c|c|}
\hline \multirow[b]{2}{*}{ Lithology } & \multicolumn{6}{|c|}{ Block properties } & \multicolumn{5}{|c|}{ Contact properties } \\
\hline & $\begin{array}{l}\text { Density } \\
\left(\mathrm{kg} / \mathrm{m}^{3}\right)\end{array}$ & $\begin{array}{c}K \\
(\mathrm{GPa})\end{array}$ & $\begin{array}{c}G \\
(\mathrm{GPa})\end{array}$ & $\begin{array}{c}\mathrm{C} \\
(\mathrm{MPa})\end{array}$ & $\begin{array}{l}F \\
\left({ }^{\circ}\right)\end{array}$ & $\begin{array}{c}\mathrm{T} \\
(\mathrm{MPa})\end{array}$ & $\begin{array}{c}\mathrm{K}_{\mathrm{N}} \\
(\mathrm{GPa} / \mathrm{m})\end{array}$ & $\begin{array}{c}\mathrm{K}_{\mathrm{s}} \\
(\mathrm{GPa} / \mathrm{m})\end{array}$ & $\begin{array}{c}\mathrm{C} \\
(\mathrm{MPa})\end{array}$ & $\begin{array}{l}F \\
\left({ }^{\circ}\right)\end{array}$ & $\begin{array}{c}\mathrm{T} \\
(\mathrm{MPa})\end{array}$ \\
\hline Overlying strata & 2500 & 0.85 & 0.64 & 1.3 & 30 & 0.8 & 118.5 & 47.4 & 1.31 & 30 & 0.31 \\
\hline Fine sandstone & 2850 & 2.56 & 1.76 & 2.6 & 31 & 1.5 & 258.2 & 103.3 & 1.51 & 31 & 0.31 \\
\hline Mudstone & 1850 & 0.92 & 0.45 & 0.7 & 25 & 0.4 & 93.2 & 37.3 & 1.32 & 27 & 0.27 \\
\hline $\begin{array}{c}\text { Sandy } \\
\text { mudstone }\end{array}$ & 2300 & 1.31 & 0.75 & 1.0 & 23 & 0.6 & 129.1 & 51.6 & 1.38 & 27 & 0.38 \\
\hline Siltstone & 2700 & 1.91 & 1.26 & 2.1 & 30 & 1.3 & 217.3 & 86.9 & 1.44 & 28 & 0.23 \\
\hline Mudstone & 1850 & 0.92 & 0.45 & 0.7 & 25 & 0.4 & 93.2 & 37.3 & 1.32 & 27 & 0.27 \\
\hline Coal seam & 1650 & 0.74 & 0.30 & 4.0 & 33 & 0.2 & 83.3 & 33.3 & 1.15 & 33 & 0.23 \\
\hline Mudstone & 1850 & 0.92 & 0.45 & 0.7 & 25 & 0.4 & 93.2 & 37.3 & 1.32 & 27 & 0.27 \\
\hline Fine sandstone & 2850 & 2.56 & 1.76 & 2.6 & 31 & 1.5 & 258.2 & 103.3 & 1.51 & 31 & 0.31 \\
\hline Siltstone & 2700 & 1.91 & 1.26 & 2.1 & 30 & 1.3 & 217.3 & 86.9 & 1.44 & 28 & 0.23 \\
\hline
\end{tabular}

\subsection{Simulation scheme}

A numerical model was performed adopting UDEC, based on the case of a deep coal mine. The length and height of the model were $100 \mathrm{~m}$ and $60 \mathrm{~m}$, respectively, as shown in Figure 7. To improve computational efficiency, the average edge length of the rectangular blocks for the coal seam in the UDEC model was set to $0.5 \mathrm{~m}$. The average edge length of rectangular blocks of the immediate roof and main roof were set to $0.25 \mathrm{~m}$ and $0.5 \mathrm{~m}$, respectively. A graded increasing edge length of rectangular blocks above the coal seam was used to avoid a sudden large increase in the block size, enhancing the calculation's accuracy. Since the buried depth of the roadway was $300 \mathrm{~m}, 7.5 \mathrm{MPa}$ was applied to the model top to represent the overlying rock load. The lateral boundary displacement of the model was constrained in the horizontal direction. The displacements of the bottom boundary were fixed in the horizontal and vertical directions. The Mohr-Coulomb failure criterion was chosen for the model. 


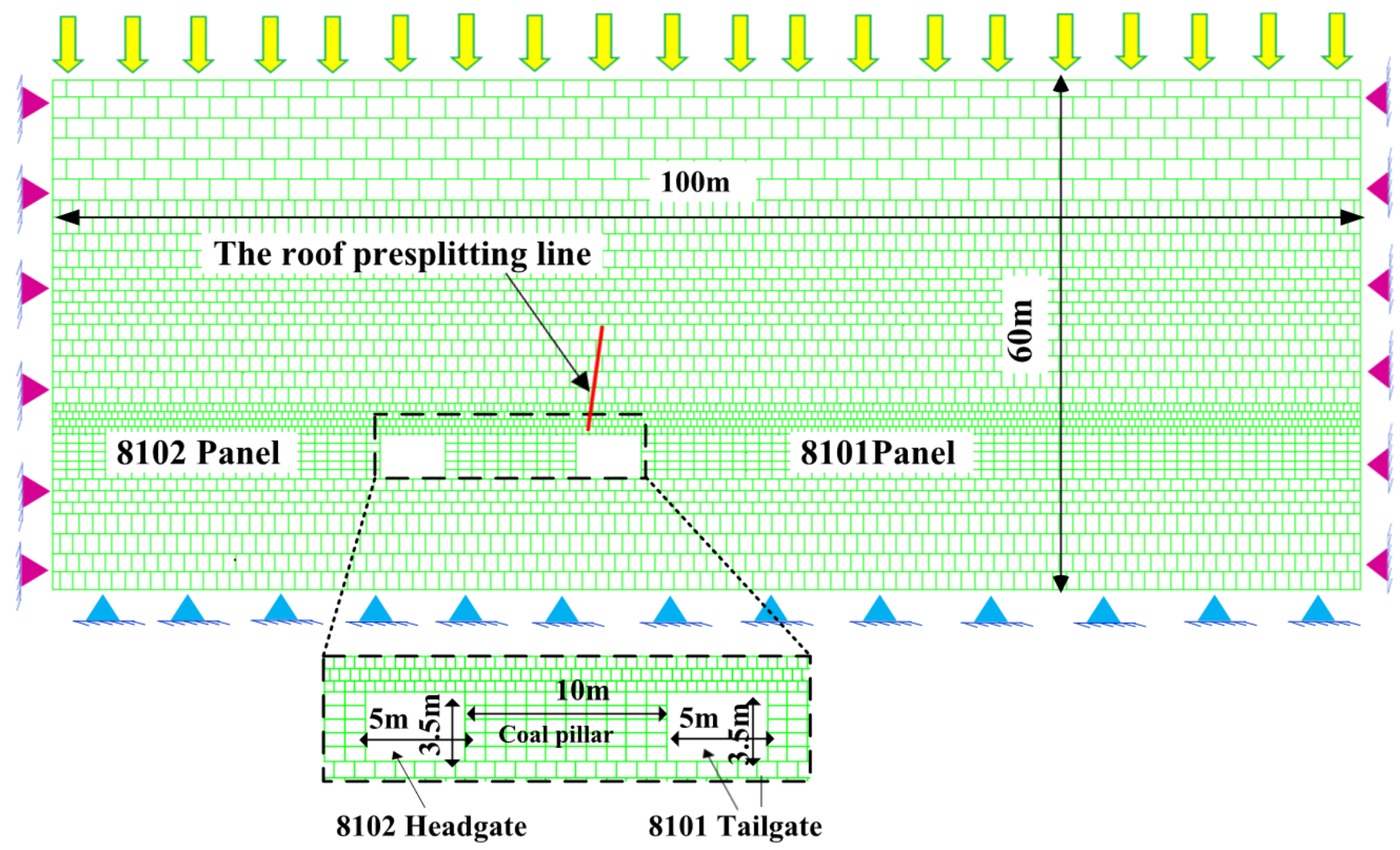

Figure 7:The numerical model built by UDEC.

The model was run to equilibrium to simulate a real stress state before roadway excavation and panel retreat. The numerical study consisted of the following stages:

1. After the stress balance, the 8101 tailgate is excavated through deleting the blocks of roadway.

2. For both the roof presplitting and non-presplitting conditions, the 8102 headgate is excavated.

3. The 8101 panel is excavated by means of stepwise retreat. From right to left in the model, each step involves a $5 \mathrm{~m}$ excavation of the 8101 panel.

\subsection{Simulation results}

\subsubsection{Fracture characteristics of the RCP structure}

To reduce the load borne by the coal pillar and release the high stress of the roadway, it is necessary to control the relative movement between the roadway roof and the goaf roof. In the process, the roof presplitting angle becomes the key to alleviating the stress concentrations of the surrounding rock. The suitable roof presplitting angle not only facilitates rock mass caving but also reduces the dynamic disturbance from caving to the roadway. Figure 8 shows the fracture characteristics of roof strata in the goaf under different roof presplitting conditions. 


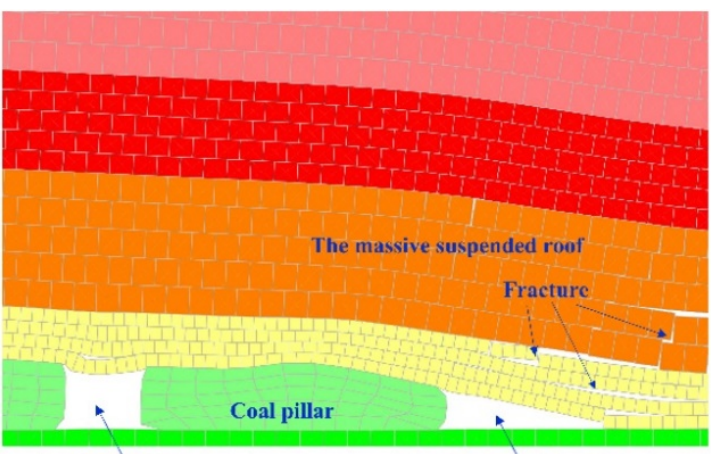

Non-filled area

(a) Non-presplitting roof

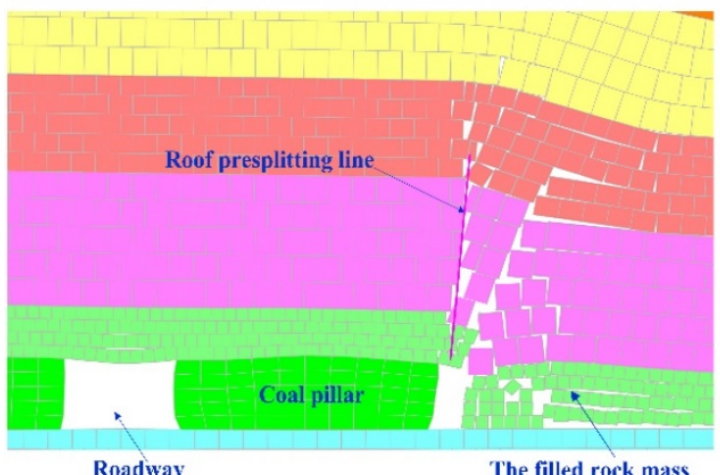

(c) $5^{\circ}$ roof presplitting angle

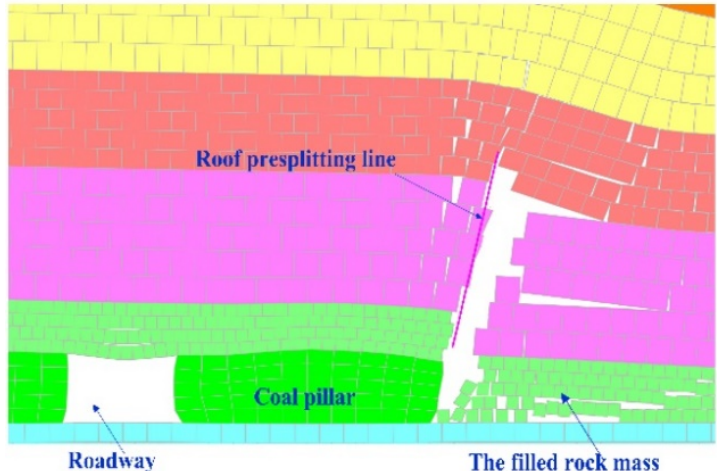

(e) $15^{\circ}$ roof presplitting angle

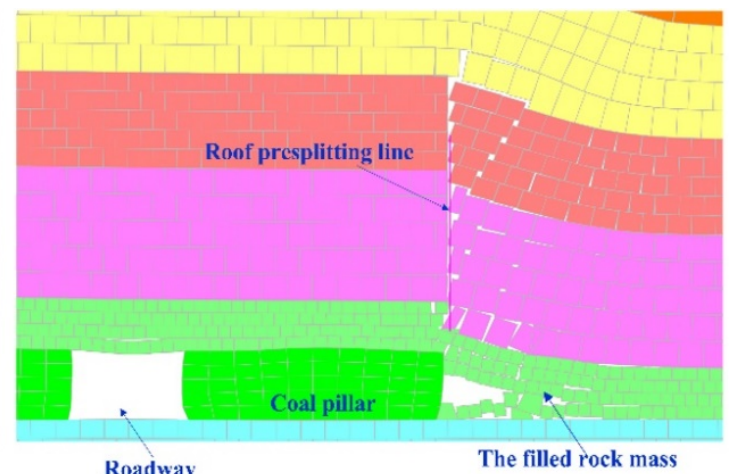

(b) $0^{\circ}$ roof presplitting angle

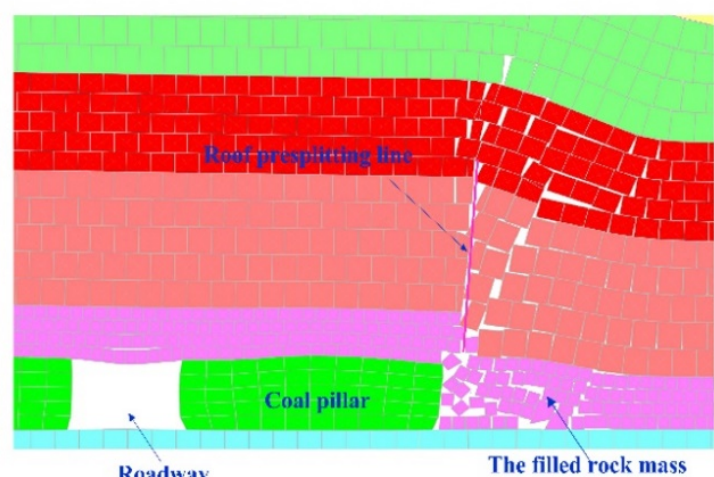

(d) $10^{\circ}$ roof presplitting angle

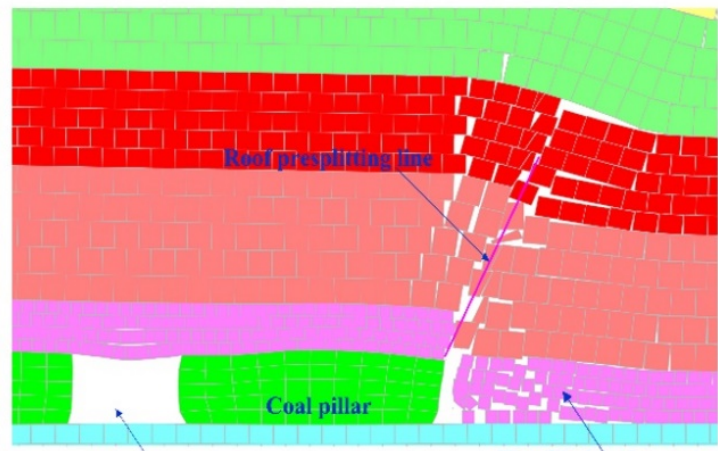

The filled rock mass

(f) $20^{\circ}$ roof presplitting angle

Figure 8: The fracture characteristics of roof strata in goaf under different roof presplitting conditions

As illustrated in Figure 8a, under a non- presplitting roof, the roof strata are inclined to the goaf at a certain angle and form a massive suspended roof above the roadway. As the strata exceed their tensile strengths, they fracture at different positions. The fractured rock mass in the goaf has a poor filling effect and fails to support the upper rock mass. Because of the larger load from the upper strata, the coal pillar is subjected to deformation and failure. Figure $8 \mathrm{~b}$ and Figure $8 \mathrm{c}$ display the fracture form of the rock strata for $0^{\circ}$ and $5^{\circ}$ roof presplitting angles. Due to the frictional force of the roof presplitting area, the subsidence speed of the broken rock mass decreases, leading to an incomplete collapse of the rock strata. The fractured rock masses are meshed with each other, and part of the stress is exerted in the horizontal direction in the coal pillar. As can be seen in Figure $8 \mathrm{~d}$, when the roof presplitting angle is $10^{\circ}$, the rock strata are rapidly cut off along the presplitting line, and there is a dramatic decrease in the frictional force between the roadway and goaf roofs. The collapsed rock mass in the goaf was compacted to form a stable load-bearing structure that was in close contact with the upper strata, slowing the rotational deformation of the roof strata and effectively reducing the load 
borne by the coal pillar. When the roof presplitting angle increased to $15^{\circ}$ and $20^{\circ}$, the damage zone of the rock mass in the fractured area continued to expand (Figure $8 \mathrm{e}$ and Figure 8f). With an increase in roof fracturing length, the upper strata load borne by the coal pillar increased, which was unfavourable for maintaining the stability of the surrounding rock.

Based on the above discussion, the suitable angle for roof presplitting was determined to be $10^{\circ}$, as shown in Figure $8 d$.

\subsubsection{Stress change law}

Figure 9 shows the distribution of vertical stress at two ribs of the roadway (8102 headgate) with roof presplitting and roof non-presplitting conditions. It is worth noting that the monitoring data of the curves represents the middle part of two ribs in the roadway.

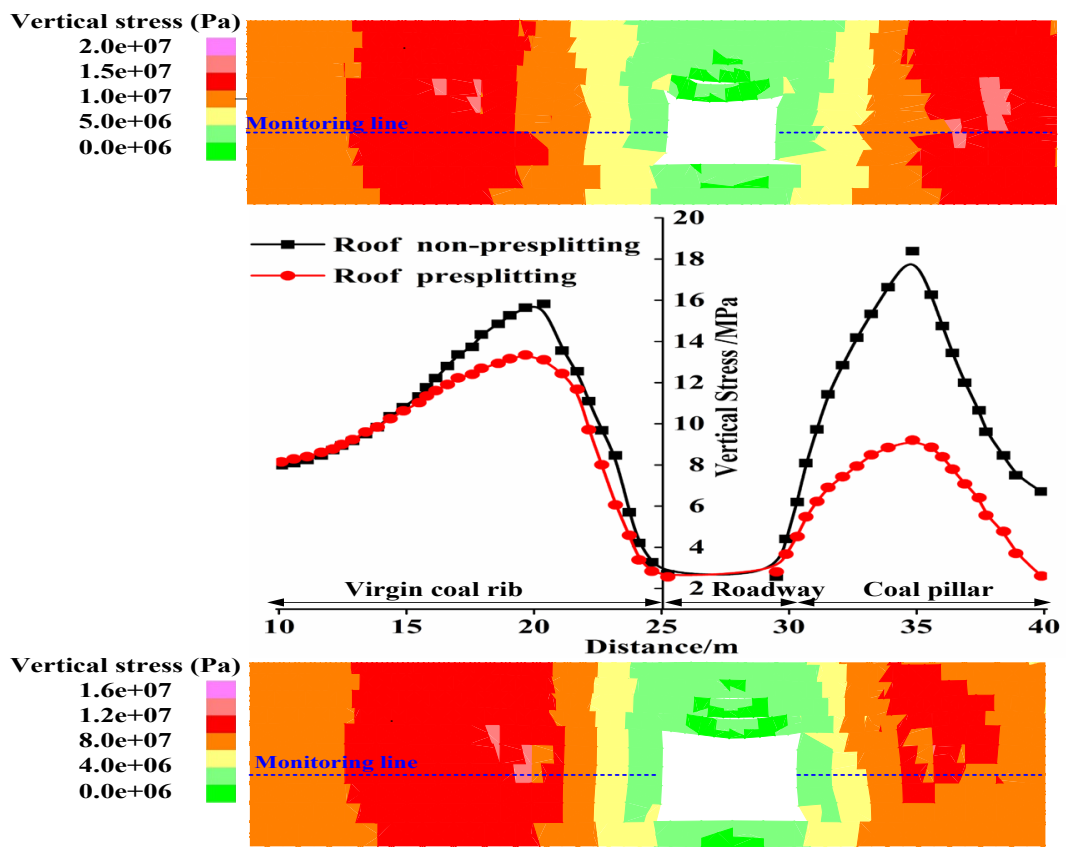

Figure 9: Vertical stress distribution of two ribs in roadway under roof presplitting and roof non-presplitting conditions.

As shown in Figure 9, because of the massive suspended roof, obvious stress concentration occurred at both ribs of the roadway under the roof non-presplitting condition. The vertical stress of the coal pillar and the virgin coal rib was distributed in a double-peak shape, and the peak values of stress were 18.2 $\mathrm{MPa}$ and $15.8 \mathrm{MPa}$, respectively. The roadway was in a high stress state. When the massive suspended roof disappeared, i.e., under the roof presplitting condition, the stress concentration of the two ribs was obviously relieved (Figure 9). The stress peak value of the coal pillar was reduced to $9.8 \mathrm{MPa}$, and the stress peak value of the virgin coal rib was lowered to $13.5 \mathrm{MPa}$. In other words, disappearance of the massive suspended roof reduced the overlying strata load borne by the coal pillar and the virgin coal rib, which kept the roadway in a lower stress state. The simulation results indicate that the existence of the massive suspended roof not only affected the stress distribution in the two ribs of the roadway but also affects the supporting role of the fractured rock mass in the goaf. Therefore, we can prevent the stress transfer from the goaf roof to the roadway roof and alleviate the roadway stress concentration via roof presplitting. 


\subsubsection{Plastic zone distribution}

Previous underground engineering accidents show that the loss of stability for the roadway is associated with the propagation of a plastic zone. Therefore, it is significant to carry out research on the plastic evolution law of rock mass. Figure 10 reveals the distribution of the plastic zone of 8102 headgate after completion of the adjacent panel retreat. The tensile failure and yield zone are marked by magenta and pink, respectively.

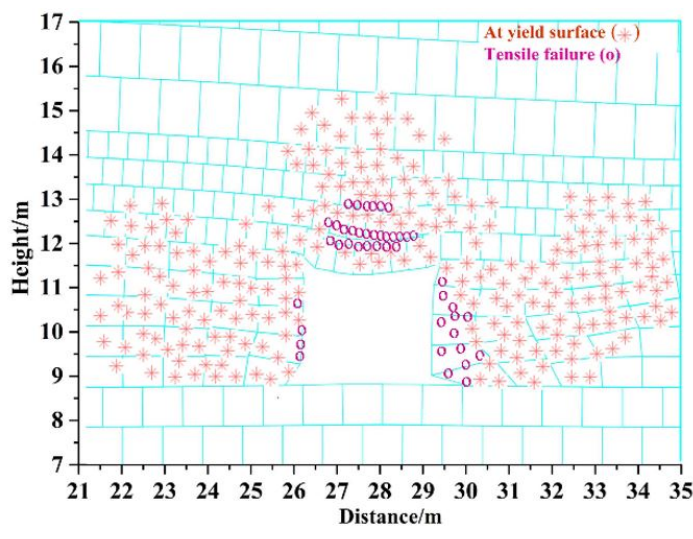

(a) Before roof fracturing

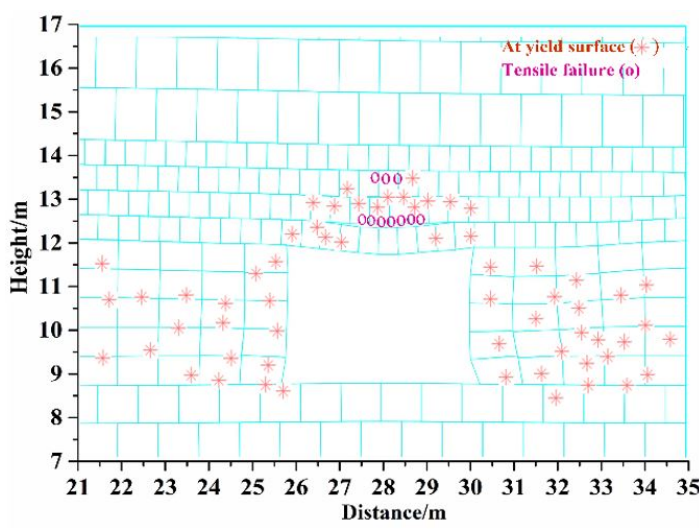

(b) After roof fracturing

Figure 10: Plastic evolution law of roadway.

Before the roof presplitting process is implemented, a fracture zone caused by tensile crack occurs on the shallow roof of the roadway (Figure 10a) because the tensile stress of the stratum exceeds its tensile strength under the combination of in-situ stress and mining-induced stress, causing separation and sliding of the roof. The fracture zone expands towards the two ribs and forms a wide range of plastic yield zones, eventually resulting in the yield of a coal pillar. After performing the roof presplitting process, the extent of tensile failure to the roadway roof decreases and the integrity of the strata is improved. The supporting effect of the broken rock mass in the goaf alleviates the load on both ribs of the roadway, and the yield range of the coal pillar and the virgin coal rib decreases (Figure 10b). From plastic distribution law, we can conclude that, before the roof presplitting process, the RCP is one part of the goaf roof and their movements are closely associated. After the roof presplitting process, the stress propagation path between the rock strata above the roadway is interrupted, and the roof extrusion and separation tendency caused by tensile failure are controlled. As a result, the stability of two ribs in the roadway is enhanced.

\section{SIMILAR MATERIAL TEST}

\subsection{Similar material test scheme}

\subsubsection{Determination of similarity constants}

To verify the reliability of the simulation results for the high-stress roadway with roof presplitting condition, a similar material test was conducted based on the layout of the panel and roadway. To more accurately represent properties of the rock mass, the determination of the similarity constants is quite important. According to studies performed by many other scholars (Huang et al. 2013, Ghabraie et al. 2015), the similarity constants should satisfy the following equations:

$\frac{\mathrm{C}_{\sigma}}{\mathrm{C}_{1} \mathrm{C}_{\gamma}}=1, \quad \mathrm{C}_{\sigma}=\frac{\sigma_{\mathrm{m}}}{\sigma_{\mathrm{p}}}, \mathrm{C}_{1}=\frac{\mathrm{L}_{\mathrm{p}}}{\mathrm{L}_{\mathrm{m}}}, \quad \mathrm{C}_{\gamma}=\frac{\gamma_{\mathrm{m}}}{\gamma_{\mathrm{p}}}$ 
where $\mathrm{C}_{\sigma}$ is the stress similarity constant; $\mathrm{C}_{1}$ is the dimension similarity constant; and $\mathrm{C}_{\gamma}$ is the volume density similarity constant. The subscript $p$ denotes prototype, and the subscript $m$ denotes similar model.

Based on the dimension of similar materials model and laboratory equipment, the geometric similarity constant and the volume density similarity constant are determined to be 50 and 0.6, respectively, i.e. $C_{1}=50$ and $C_{\gamma}=0.6$. According to the similarity theory, other similarity constants can be obtained:

$\frac{\mathrm{C}_{\sigma}}{\mathrm{C}_{\mathrm{E}} \mathrm{C}_{\varepsilon}}=1, \mathrm{C}_{\varepsilon}=\mathrm{C}_{\mathrm{f}}=\mathrm{C}_{\mu}=1$

where $\mathrm{C}_{\mathrm{E}}$ is the elasticity modulus similarity constant; $\mathrm{C}_{\varepsilon}$ the strain similarity constant; $\mathrm{C}_{\mathrm{f}}$ is the friction angle similarity constant; and $\mathrm{C}_{\mu}$ is the Poisson's ratio similarity constant.

In this test, the similar materials were composed of river-sand, calcium carbonate, gypsum, mica powder, and water. In order to achieve the rock properties in similar test, various uniaxial compression tests were performed on the cylinder specimens made of similar materials (Figure 11). Based on numerous tests, the mechanical parameters of the different compositions were compared and selected to ensure that the similar materials could meet the requirements of engineering rock mass (Li et al. 2015). The rock properties in similar material test are shown in Table 3.

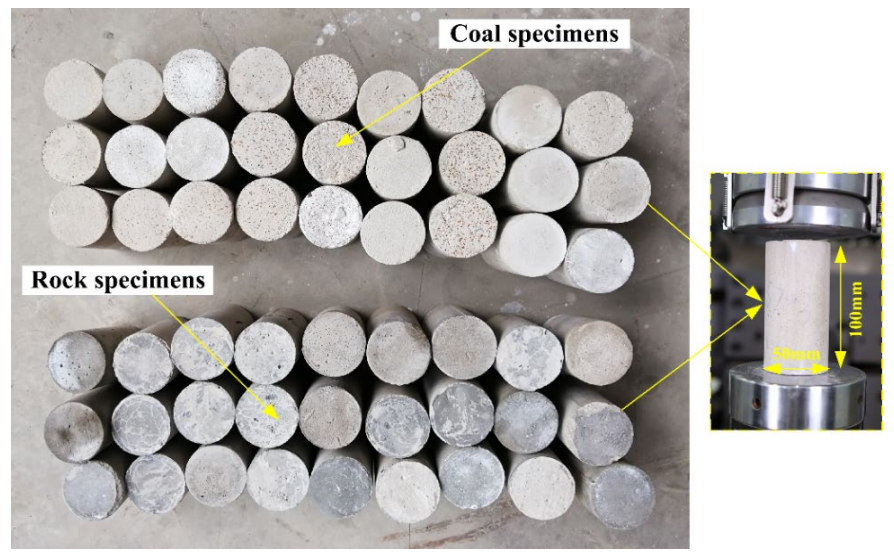

Figure 11: Some cylindrical specimens made of similar materials.

Table 3: The rock properties in similar material test.

\begin{tabular}{ccccc}
\hline Lithology & & Compressive Strength/ MPa & Young's modulus /GPa & Poisson's ration \\
\hline \multirow{2}{*}{ Fine sandstone } & prototype & 15.7 & 4.3 & 0.14 \\
& model & 0.52 & 1.9 & 0.22 \\
Sandy mudstone & prototype & 7.3 & 0.06 & 0.26 \\
Siltstone & model & 0.24 & 3.1 & 0.23 \\
& prototype & 12.6 & 0.10 & 0.29 \\
Mudstone & model & 0.42 & 1.2 & 0.04 \\
Coal seam & model & 3.5 & 0.3 & 0.03 \\
\hline
\end{tabular}




\subsubsection{Similar test system}

The similar test was carried out in the State Key Laboratory for Geomechanics and Deep Underground Engineering, China University of Mining and Technology. In this study, the dimensions of the test framework were $2200 \times 1200 \times 200$ $\mathrm{mm}$ (length $\times$ height $\times$ width), and the corresponding roadway dimensions were $100 \mathrm{~mm} \times 70 \mathrm{~mm}$ (length $\times$ height). The structure schematic of the test device is shown in Figure 12. The left, right, and bottom parts of the test frame are composed of cast steel frames, which can simulate the displacement boundary conditions of the numerical model. The top part of the frame was the loading system developed by the China University of Mining and Technology. The loading system consisted of 15 cylinders, each of which could generate a flexible load intensity of 1 MPa (Figure 12). The cylinders were controlled by the loading control system, and the loading and unloading process could be realized in the vertical direction. All of these cylinders could apply uniform and simultaneous pressure on the top of the model.

The stress monitoring system was composed of a strain acquisition system and pressure cells. The strain acquisition system was characterized by a high accuracy and continuous measurement. The pressure cell had a diameter of 30 mm and a height of $7 \mathrm{~mm}$, and the sensitivity of each cell was 40 microstrain, as shown in Figure 13 . The roadway displacement was measured using multi-point extensometers (Figure 13) and a digital photography system (Figure 14). The accuracy of the grating multi-point extensometers was 1,600,000 effective pixels.

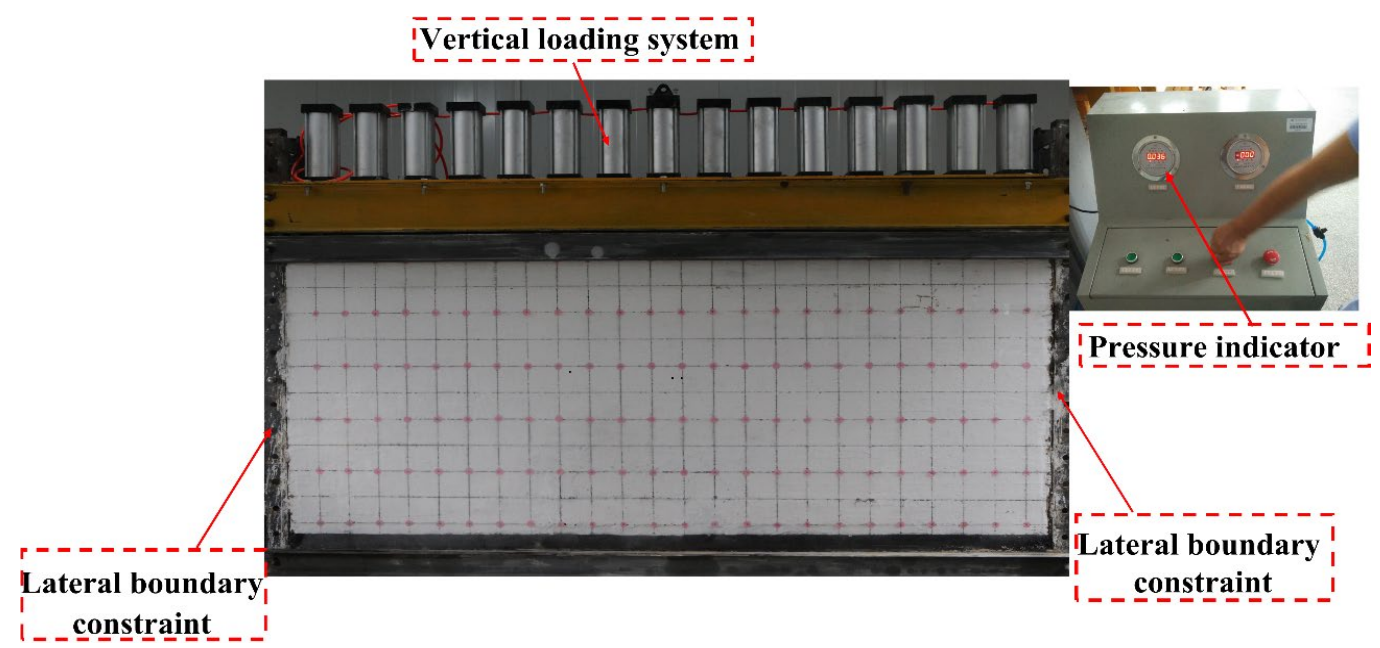

Figure 12: Similar materials model.

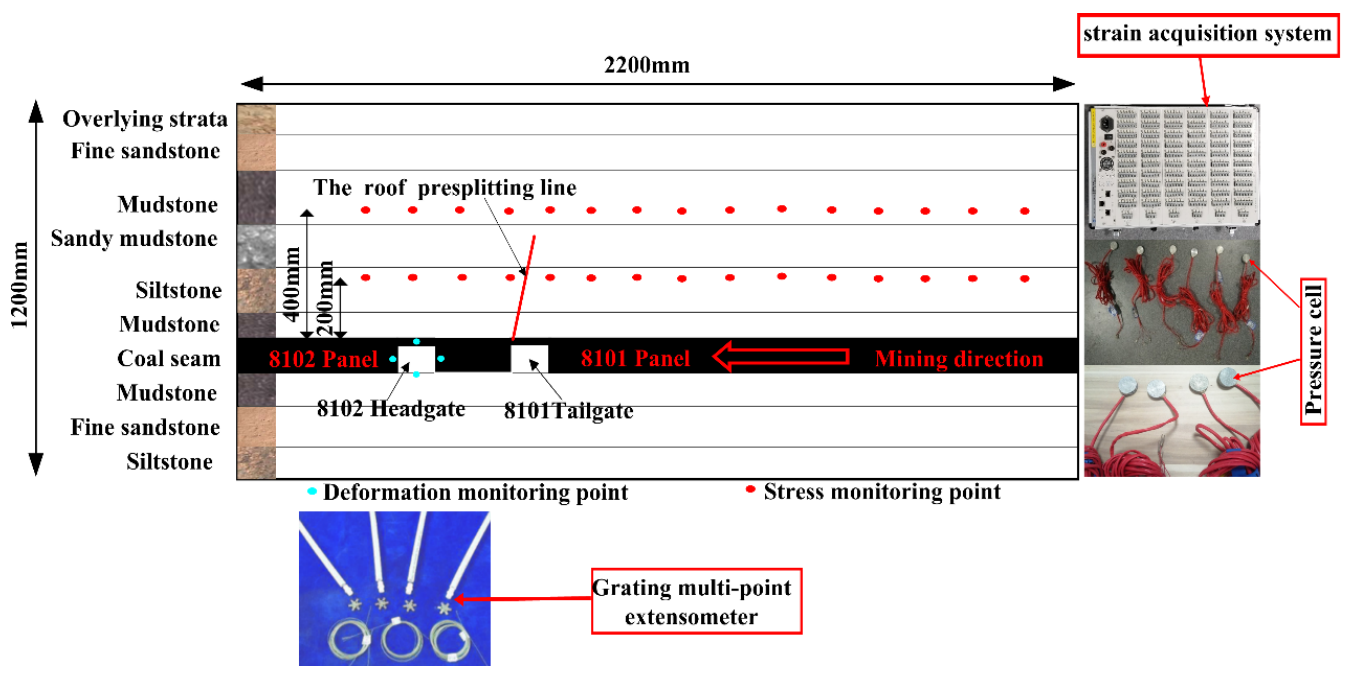

Figure 13: Layout for the similar material test. 


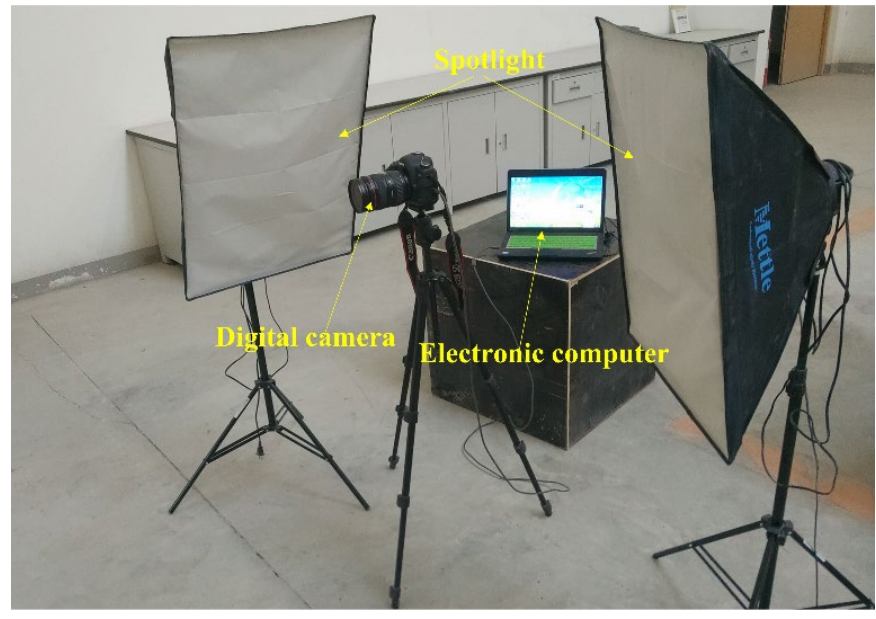

Figure 14: Digital photographic system.

\subsubsection{Similar test procedure}

\section{(1)Test model establishment}

The similar materials were filled and rammed in order to establish the model according to the scheme. First, the monitoring points of the stress, displacement and position of the presplitting line for pouring easily materials to the model were marked. Second, the similar materials were filled into the frame. The pressure cells were placed 200 and 400 $\mathrm{mm}$ away from the coal seam, respectively. Four grating multi-point extensometers were embedded into the surface around the designed roadway during the pouring process. Then, $1 \mathrm{~mm}$ thick mica powder was paved between the layers of rock to simulate the presplitting line with a height of $320 \mathrm{~mm}$ according to the geometric similarity ratio. Finally, the similar materials were rammed until the test model was completed.

(2)Simulation of load application

On the basis of the stress similarity constant, $0.25 \mathrm{MP}$ of vertical stress was loaded onto the top of the model, corresponding to the buried depth of $300 \mathrm{~m}$ in reality. The loading process was divided into five steps, and the increment in each loading step loading was 0.05 MPa every half hour, until the vertical stress reached $0.25 \mathrm{MPa}$. It took approximately $2 \mathrm{~h}$ to reach the designed in-situ stress and to remain stable.

(3) Roadway excavation and panel retreat

The data acquisition system to record the data of the pressure cells and grating multi-point extensometers were switched on. The roadway excavation and panel retreat were completed through artificial drilling. According to the test scheme, the 8101 tailgate and the 8102 headgate were excavated in sequence. From the right side of the model, the retreat of the 8101 panel was accomplished in twelve steps. The 8101 panel retreated over $100 \mathrm{~mm}$ for each step, corresponding to $5 \mathrm{~m}$ in the numerical simulation. The digital photography system was turned on and took a picture every 10 seconds. When the 8101 panel was excavated and the stress and displacement data were stable, the similar model test ended.

\subsection{Results of the similar material test}

\subsubsection{Accumulation characteristics of the collapsed rock mass}

Figure 15 shows the accumulation forms of the collapsed rock mass predicted by the similar material test and numerical simulation after the roof presplitting. It can be seen that results of the similar material test and the numerical simulation matched well in many features, including collapsed roof pattern and distribution characteristics of rock mass in the goaf. As shown in Figure 15a, the RCP was broken along the roof presplitting line and was fractured into different 
shapes of masses. The rock masses rotated, touched each other, and accumulated during the process of collapse. Due to the bulking characteristics, the volume of rock masses in the broken state was larger than that of the original rock strata. The collapsed rock mass was compacted to form a stable load-bearing structure that was in close contact with the upper strata. Under the effective support by the lower rock masses, the overlying strata bent and subsided synchronously, avoiding the dynamic disturbance to the surrounding rock caused by the sudden fracture of the strata.

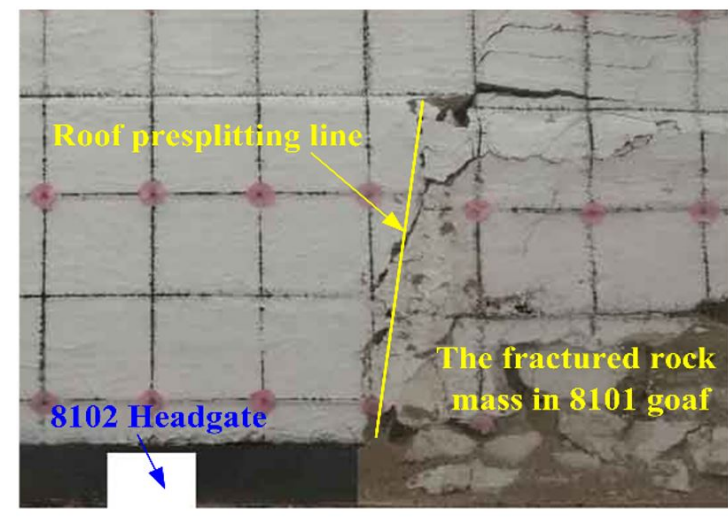

(a) The similar test result

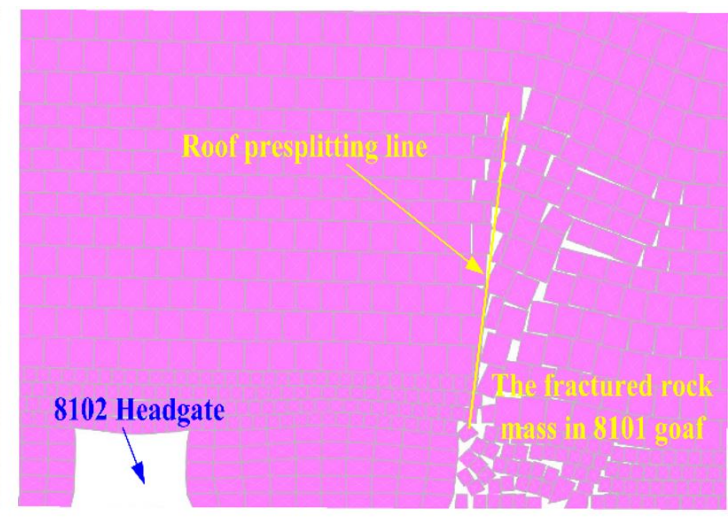

(b) Numerical simulation result

Figure 15: Accumulation forms of the collapsed rock mass.

\subsubsection{Stress distribution of the roof strata in the goaf}

Two stress measuring lines (Figure 13) were respectively placed at positions $200 \mathrm{~mm}(10 \mathrm{~m}$ in reality) and $400 \mathrm{~mm}$ (20m in reality) above the coal seam to measure the vertical stress of the roof strata under the influence of the rock presplitting. Figure 16 shows the vertical stress variation of roof strata in the goaf. The change trend of stress obtained from the similar material test was consistent with that predicted by the numerical simulation.

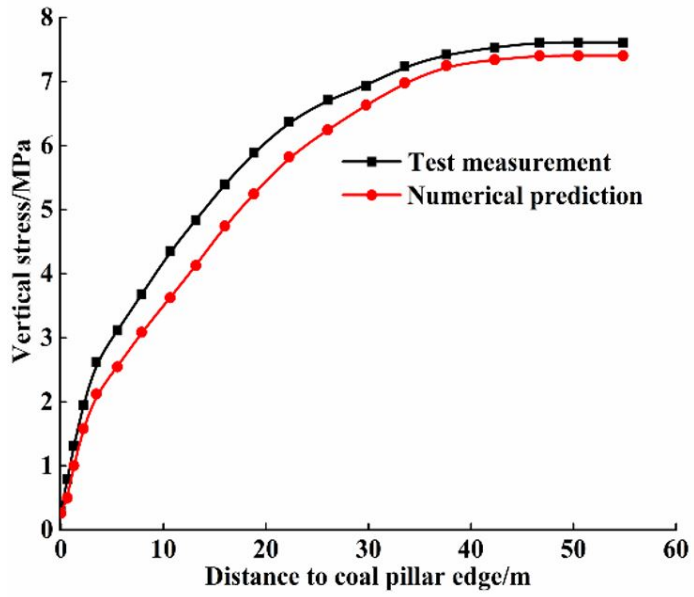

(a) $10 \mathrm{~m}$ above the coal seam

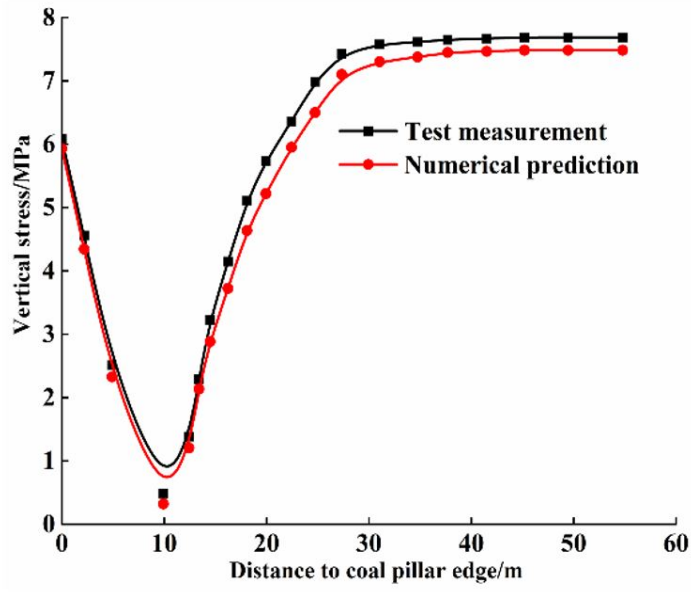

(b) $20 \mathrm{~m}$ above the coal seam

Figure 16: Vertical stress variation of the roof strata in the goaf.

As shown in Figure 16a, the vertical stress of the coal pillar edge was $0.3 \mathrm{MPa}$. As the distance from the coal pillar edge increased, the vertical stress gradually increased. When the distance from the coal pillar edge was approximately $52 \mathrm{~m}$, the vertical stress reached a maximum value of 7.4 MPa and then remained unchanged. The lower vertical stress 
of the coal pillar edge indicated that the RCP was completely broken along the presplitting line. When the distance from the edge of the coal pillar was $52 \mathrm{~m}$, the vertical stress was close to the initial stress (7.5 MPa), which indicated that the collapsed rock masses in the goaf had been compacted and consolidated. In other words, $99 \%$ (7.4/7.5) of the roof strata load was borne by the collapsed rock masses. As is shown in Figure 16b, the vertical stress of the rock strata above the goaf first reduced and then increased. Since the upper strata load borne by the coal pillar decreased after the roof presplitting process, the vertical stress of roof strata was reduced from 6.2 to $0.8 \mathrm{MPa}$. As the broken rock masses in the goaf were compacted, the supporting effect of the lower rock strata on the upper rock strata was enhanced, and the vertical stress of the roof strata was gradually increased to the initial stress. The results of the similar material test and the numerical simulation show that roof presplitting alleviated the stress concentration of the coal pillar and that the rock mass filling further reduced the overlying strata load borne by the coal pillar, thereby improving the stability of the coal pillar.

\subsubsection{Deformation law of roadway}

Figure 17 shows the simulated deformation vector diagram of the 8102 headgate after the 8101 panel retreat, under the roof presplitting condition. The deformation comparison of the 8102 headgate during the 8101 panel retreat is shown in Figure 18. The deformations of the P1, P2, P3, and P4 monitoring points in the similar material test were 238.4, 88.5, 118.3 , and $25.1 \mathrm{~mm}$, respectively. The deformations of the P1, P2, P3, and P4 monitoring points in the numerical simulation are 224.1, 81.2, 110.7, and $23.3 \mathrm{~mm}$, respectively. There was a good agreement between the simulation and the similar test in terms of deformation result. The results of the similar test confirmed that the application of the roof presplitting and rock mass filling was feasible in controlling the deformation of the roadway.

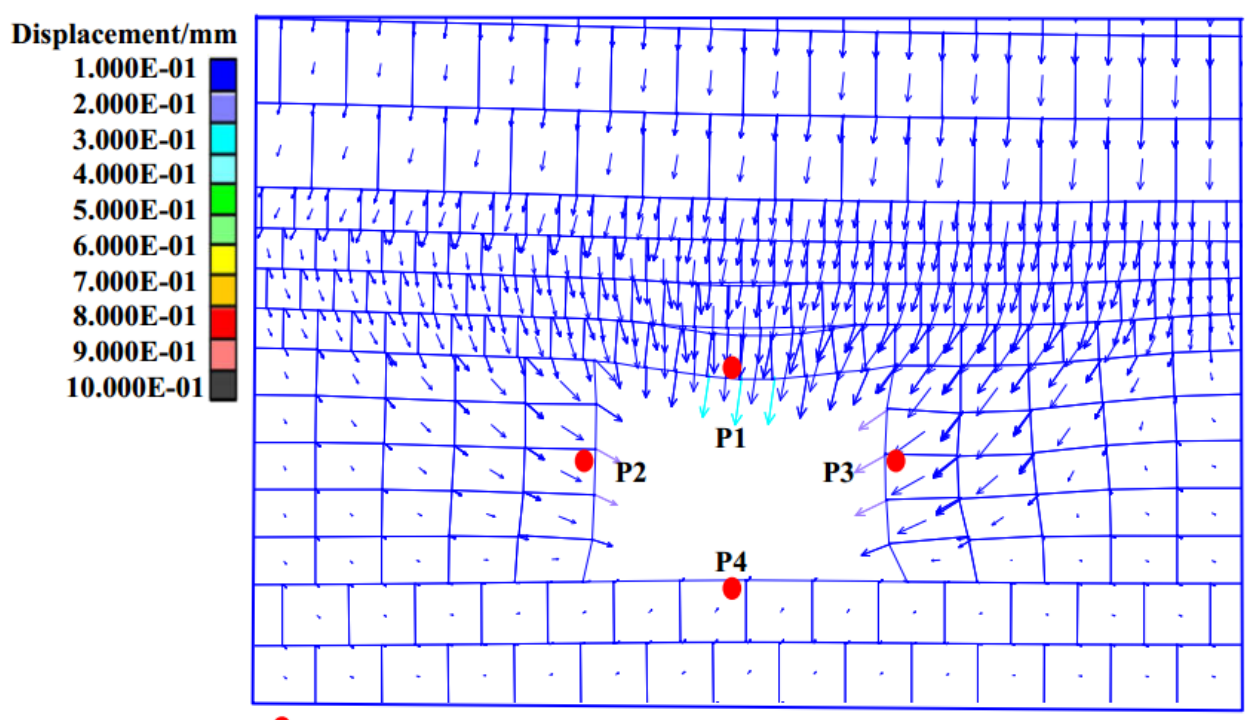

Monitoring point

Figure 17: The simulated deformation vector diagram of 8102 headgate with the roof presplitting condition. 


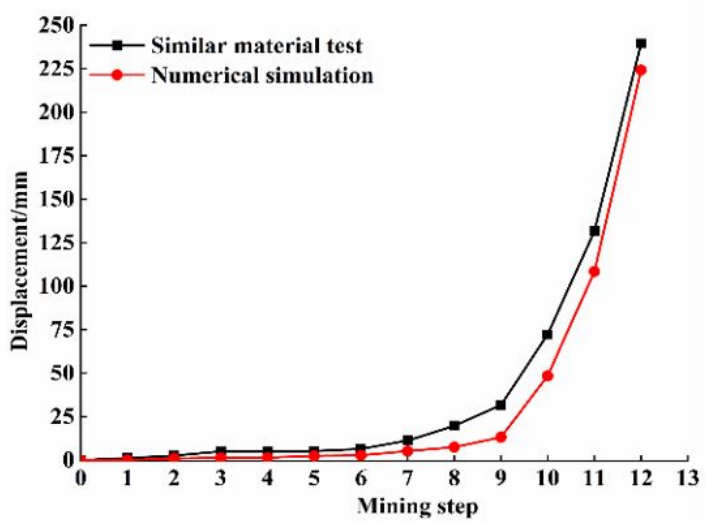

(a) P1 monitoring point

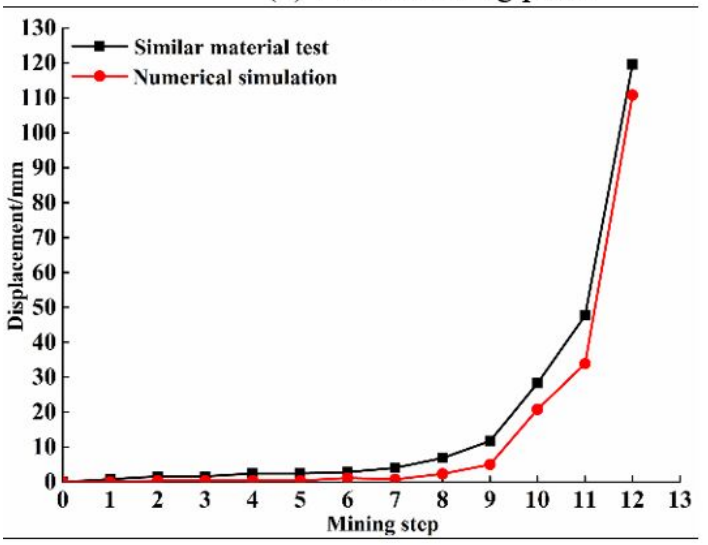

(c) P3 monitoring point

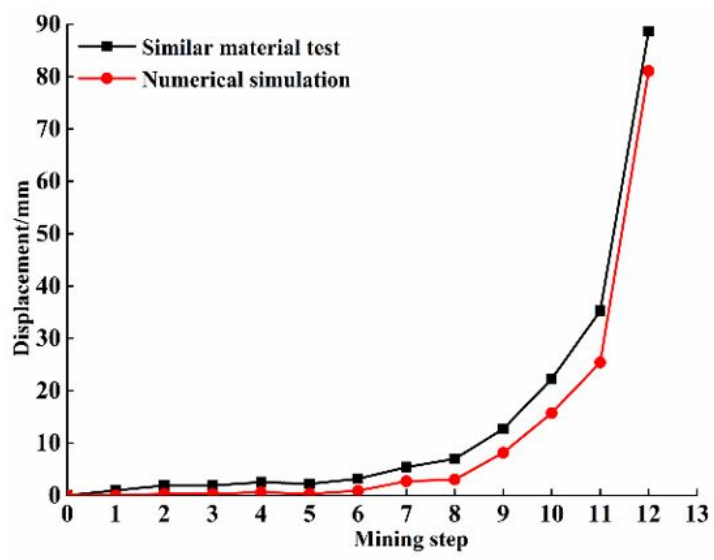

(b) P2 monitoring point

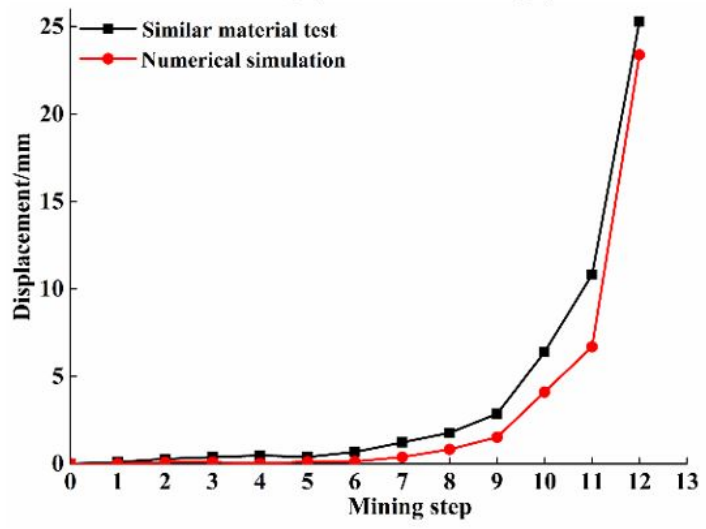

(d) P4 monitoring point

Figure 18: Deformation comparison of the roadway during panel retreat.

\section{DISCUSSION}

After excavation of the roadway, the mechanical behavior of the roof can be analyzed by the voussoir beam theory, which has been generally accepted as a simplified tool for investigating the stability of rock masses excavation (Diederichs and Kaiser 1999). The load of rock strata above the voussoir beam is mainly borne by two ribs of the roadway. During the panel retreat, the original balance of the main roof is strongly disturbed, and fracture of the main roof forms three types of rock masses, namely, A, B, and C, as shown in Figure 19a. Rock mass A continues to be stable, and rock mass $C$ is located above the goaf. After being broken, rock mass $B$ begins to rotate. The rotation of rock mass $B$ has an influence on the stability of the roadway. According to the limit equilibrium theory (Li et al. 2018, Cao and Zhou 2015, Yan et al. 2013), the fractured length of rock mass B can be obtained through the following equation:

$1=\frac{2 \mathrm{~L}}{17}\left[\sqrt{\left(10 \frac{\mathrm{L}}{\mathrm{S}}\right)^{2}+102}-10 \frac{\mathrm{L}}{\mathrm{S}}\right]$

where 1 is the fractured length of rock mass $B, S$ is the dip length of the panel, and $L$ is the periodic weighting length of the main roof. According to the actual field measurement, the periodic weighting length of the main roof is $20 \mathrm{~m}$, and the 8102 panel dip length is $210 \mathrm{~m}$. 


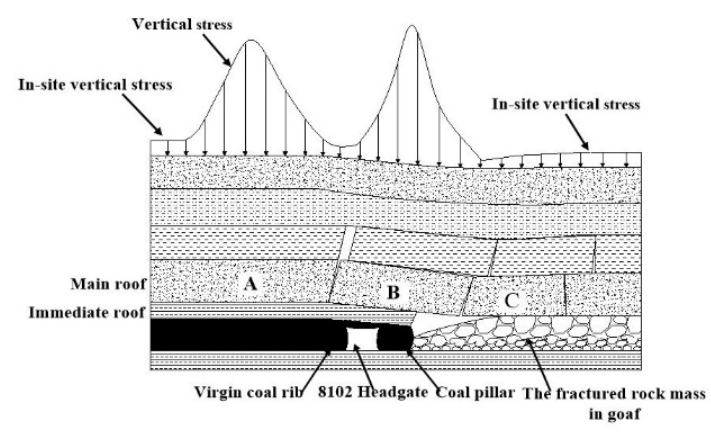

(a) Before the roof presplitting

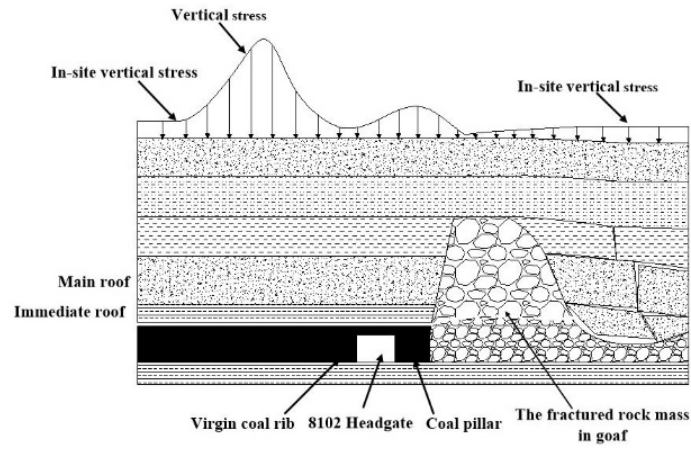

(b) After the roof presplitting

Figure 19: Failure mode of the roadway surrounding rock.

From equation (15), it can be concluded that the fractured length of rock mass B is $24.5 \mathrm{~m}$. The fractured length of $24.5 \mathrm{~m}$ has exceeded the sum of widths of the coal pillar and the roadway, indicating that there is a massive suspended roof on the RCP, which agrees with the results of the numerical simulation (Figure 8a). Due to the long massive suspended roof, the vertical stress of the coal pillar and the virgin coal rib is distributed in a double-peak shape, and the roadway is in a high-stress environment. After rock mass B breaks and rotates, the load of roof strata gradually shifts to the coal pillar. When the rock loads exceeds the bearing capacity of the coal pillar, the coal pillar undergoes deformation failure (Figure 19a), which cannot maintain the stability of the roadway.

The results of the simulation and the similar test show that, when the massive suspended roof is cut off along the roof presplitting line, the rock strata load undertaken by the coal pillar and the virgin coal rib is significantly reduced. At the same time, the collapsed rock masses fill the goaf and provide better support for the overlying strata, further limiting the rotational deformation of the overlying strata (Figure 19b). The roadway is in a good stress environment. Based on the above discussion, we find that the roof strata presplitting and broken rock mass filling could optimize the stress environment and improve the stability of roadway surrounding rock.

\section{ENGINEERING APPLICATION}

At present, directional blasting is an effective method to create a presplitting line. To reduce the dynamic disturbances on the roadway roof caused by blasting, a special energy-accumulated blasting device was adopted to obtain the directional fracturing line, as shown in Figure 20a. Perforation was carried out on the energy-accumulated blasting device (Figure 20a). During blasting, high- temperature and high-pressure gas were released from the perforation. The rock mass was tensioned in a specific direction to produce cracks without damage in other directions. When the adjacent boreholes blasted simultaneously, the crack extended quickly until it penetrated the rock to form a smooth presplitting line, as shown in Figure 20b.

To achieve the ideal presplitting line, the blasting hole spacing depends on the influence range of the blasting, based on the lithology properties of the roof. Combined with previous experience, the diameter of the blasting hole was $50 \mathrm{~mm}$ and the spacing was $1200 \mathrm{~mm}$ in the field application. The size of the energy-accumulated blasting device was $42 \mathrm{~mm}$ (diameter) $\times 2000 \mathrm{~mm}$ (length). As shown in Figure 21, blasting holes were drilled in advance on the roof strata of the 8102 tailgate to build a presplitting line. With the retreat of the 8102 panel, the roof strata of the goaf collapsed along the presplitting line (Figure 21). 


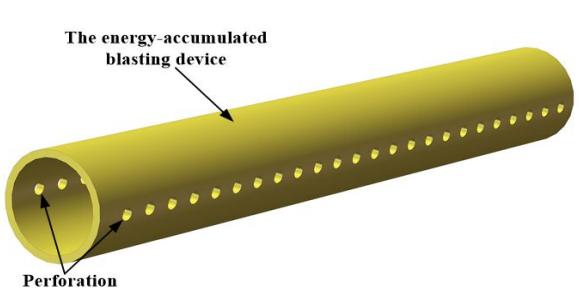

(a) The energy-accumulated blasting device

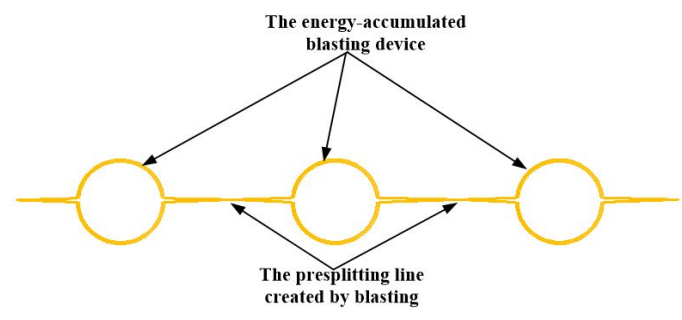

(b) The presplitting line created by blasting

Figure 20: Creation process of roof presplitting line.

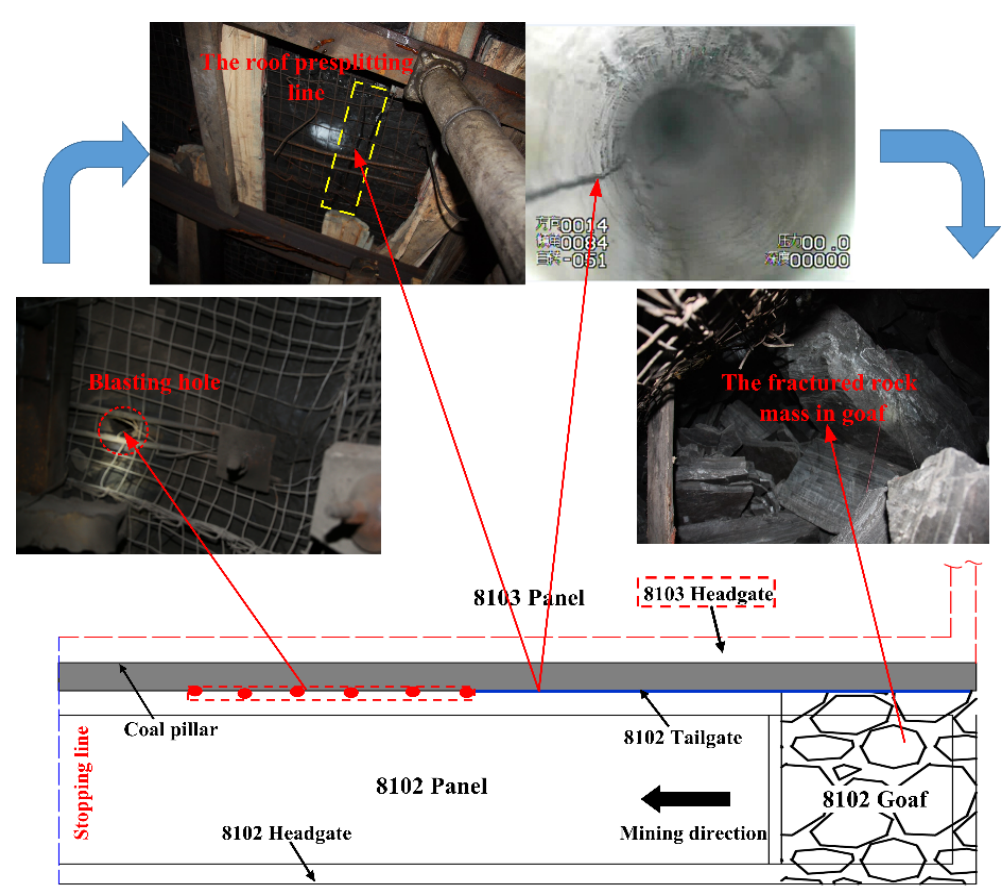

Figure 21: The field creation of the roof presplitting in 8102 tailgate.

The deformation of the surrounding rock in the 8103 headgate was monitored during the 8102 panel retreat.The monitoring data showed that after adopting the approach of the roof presplitting and rock mass filling, the total displacements of the roof, virgin coal rib, coal pillar, and floor were 227, 85, 112, and 25mm, respectively, which were in accordance with the results of the UDEC prediction, as shown in Figure 22. Compared with the deformations that occurred under the roof non-presplitting condition, the displacements of the roof, virgin coal rib, coal pillar, and floor were reduced by $75 \%, 78 \%, 82 \%$, and $83 \%$ (Figure 22 ), respectively. The stability control effect of the 8103 headgate is shown in Figure 23. 


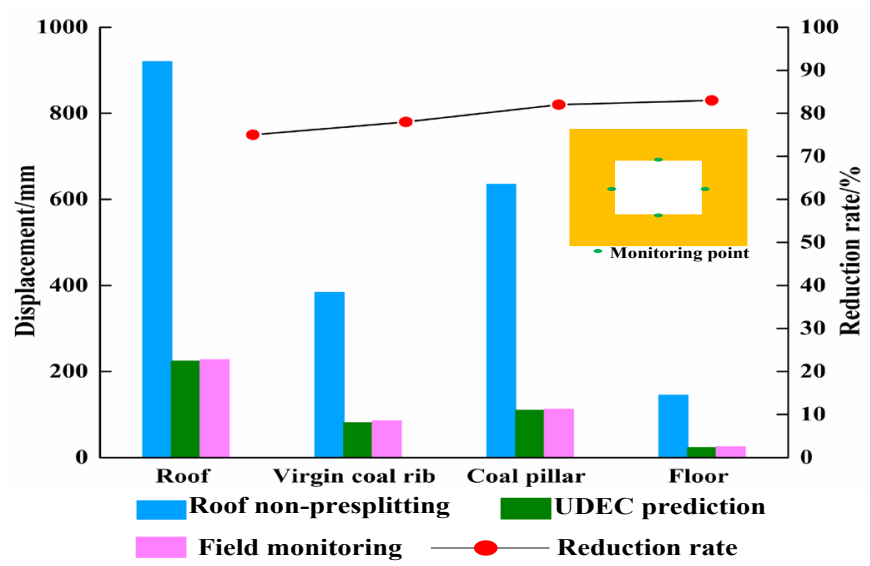

Figure 22: The displacements comparison of 8103 headgate before and after roof presplitting.

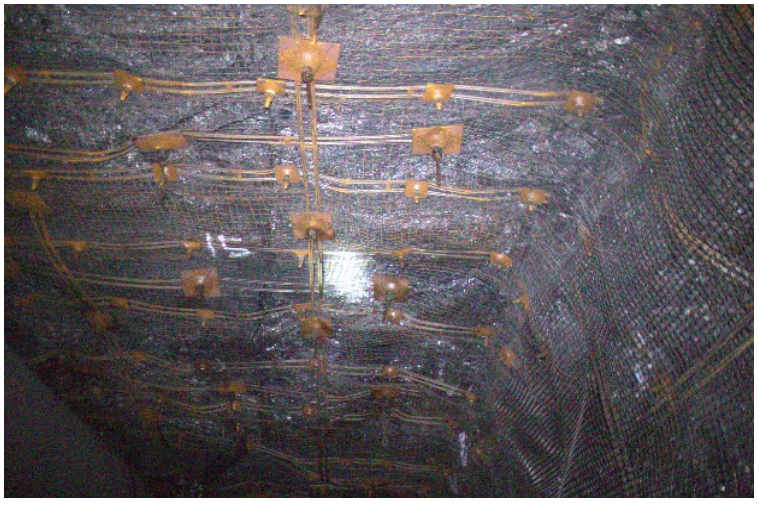

Figure 23: The stability of the surrounding rock in 8103 headgate.

\section{Conclusions}

Taking the Lu'an mining district in Shanxi Province as an example, the failure characteristics and the stability control mechanism of the deep high-stress roadway was studied via numerical simulation and the similar material test. The approach of the roof presplitting and rock mass filling was proposed to improve the stability of the roadway. The main conclusions of the paper are as follows:

(1) With the roof under the non-presplitting condition, the roadway was in a high-stress environment due to the massive suspended roof. The failure process of the high-stress roadway began with tensile crack in the shallow roof and then extended to the two ribs, resulting in the yield of a coal pillar. Under the condition that the roof was presplit, the peak value of the vertical stress at the coal pillar was decreased from 18.2 to $9.8 \mathrm{MPa}$ while that of the virgin coal rib was decreased from 15.8 to $13.5 \mathrm{MPa}$. The roadway was in a low-stress environment.

(2) The similar material test results showed that the RCP was cut off along the presplitting lines and was fractured into different sizes of masses. The broken rock mass filled in the goaf and supported on the overlying strata, which reduced the load on the coal pillar. The overlying strata bent and subsided synchronously, avoiding the dynamic disturbance to the surrounding rock caused by the sudden fracture of the strata.

(3) The engineering application was successfully performed to evaluate the applicability of controlling the large deformations of the roadways and coal bumps based on the approach of the roof presplitting and rock mass filling. Field monitoring data indicated that after adopting the approach, the stability of the high-stress roadway was obviously improved. 


\section{Acknowledgments}

The authors would like to acknowledge the support of The National Natural Science Foundation of China (No.27183004).

\section{References}

Cao, Z. Z. \& Zhou, Y. J. (2015). Research on coal pillar width in roadway driving along goaf based on the stability of key block. CMC-COMPUT MATER CONTIN, 48(2), 77-90.

Chen, M., Yang, S. Q., Zhang, Y. C. \& Zang, C. W. (2016). Analysis of the failure mechanism and support technology for the Dongtan deep coal roadway. Geomechanics and Engineering, 11(3), 401-420.

Cohen, T., Masri, R. \& Durban, D. (2009). Analysis of circular hole expansion with generalized yield criteria. International Journal of Solids and Structures, 46(20), 3643-3650.

Diederichs, M. S. \& Kaiser, P. K. (1999). Stability of large excavations in laminated hard rock masses: the voussoir analogue revisited. International Journal of Rock Mechanics and Mining Science, 36(1), 97-117.

Gao, F. Q., Stead, D. \& Kang, H. P. (2015). Numerical Simulation of Squeezing Failure in a Coal Mine Roadway due to MiningInduced Stresses. Rock Mechanics and Rock Engineering, 48(4), 1635-1645.

Ghabraie, B., Ren, G., Zhang, X. Y. \& Smith, J. (2015). Physical modelling of subsidence from sequential extraction of partially overlapping longwall panels and study of substrata movement characteristics. International Journal of Coal Geology, 140(15), 71-83.

He, M. C. (2011). Physical modeling of an underground roadway excavation in geologically $45^{\circ}$ inclined rock using infrared thermography. Engineering Geology, 121(3), 165-176.

He, M. C., Gong, W. L., Zhai, H. M. \& Zhang, H. P. (2010). Physical modeling of deep ground excavation in geologically horizontal strata based on infrared thermography. Tunnelling and Underground Space Technology, 25(4), 366-376.

Hoek, E., Carranza-Torres, C. \& Corkum, B. (2002). Hoek-Brown failure criterion-2002 Edition, in: proceedings of the 5th North American Rock Mechanics Symposium. Toronto, Canada, 267-273.

Hoek, E., Marinos, P. \& Benissi, M. (1998). Applicability of the Geological Strength Index (GSI) classification for very weak and sheared rock masses: The case of the Athens Schist Formation. Bulletin of Engineering Geology and the Environment, 57(2), $151-160$.

Huang, F., Zhu, H. H., Xu, Q. W., Cai, Y. C. \& Zhuang, X. Y. (2013). The effect of weak interlayer on the failure pattern of rock mass around tunnel - scaled model tests and numerical analysis. Tunnelling and Underground Space Technology, 35, 207-218. Itasca Consulting Group Inc. (2008). UDEC: User Manual. Version 4.0, Minneapolis, MN: ICG.

Kang, H. P. (2014). Support technologies for deep and complex roadways in underground coal mines: a review. International Journal Coal Science Technology, 1(3), 261-277.

Karampinos, E., Hadjigeorgiou, J., Hazzard, J. \& Turcotte, P. (2015). Discrete element modelling of the buckling phenomenon in deep hard rock mines. International Journal of Rock Mechanics and Mining Science, 80, 346-356. 
Li, S. C., Wang, Q., Wang, H. T., Jiang, B., Wang, D. C., Zhang, B., Li, Y. \& Ruan, G. Q. (2015). Model test study on surrounding rock deformation and failure mechanisms of deep roadways with thick top coal. Tunnelling and Underground Space Technology, 47, 52-63.

Li, X. B. \& Weng, L. (2016). Numerical investigation on fracturing behaviors of deep-buried opening under dynamic disturbance. Tunnelling and Underground Space Technology, 54, 61-72.

Li, Z., Xu, J. L., Ju, J. F., Zhu, W. B. \& Xu, J. M. (2018). The effects of the rotational speed of voussoir beam structures formed by key strata on the ground pressure of stopes. International Journal of Rock Mechanics and Mining Science, 108, 67-79.

Liu, X. R., Chen, H. J., Liu, K. \& He, M. C. (2017). Model test and stress distribution law of unsymmetrical loading tunnel in bedding rock mass. Arabian Journal of Geosciences, 10, 184-195.

Marinos, P. \& Hoek, E. (2000). GSI: a geologically friendly tool for rock mass strength estimation, Proceedings of the GeoEng2000, in: International Conference on Geotechnical and Geological Engineering, Lancaster, Melbourne, $1422-1446$. Pellet, F., Roosefid, M. \& Deleruyelle, F. (2009). On the 3D numerical modelling of the time-dependent development of the damage zone around underground galleries during and after excavation. Tunnelling and Underground Space Technology, 24(6), 665-674.

Peng, S. S. (2006). Longwall mining, 2nd edn, Morgantown, WV, USA.

Qin, C. B., Yang, X. L., Pan, Q. J. Sun, Z.B., Wang, L.L. \& Miao, T. (2015). Upper bound analysis of progressive failure mechanism of tunnel roofs in partly weathered stratified Hoek-Brown rock masses. International Journal of Rock Mechanics and Mining Science, 74, 157-162.

Read, R. S. (2004). 20 years of excavation response studies at AECL's Underground Research Laboratory. International Journal of Rock Mechanics and Mining Science, 41(8), 1251-1275.

Shabanimashcool, M. \& Li, C. C. (2013). A numerical study of stress changes in barrier pillars and a border area in a longwall coal mine. International Journal of Coal Geology, 106, 39-47.

Shen, B. T. (2014). Coal Mine Roadway Stability in Soft Rock: A Case Study. Rock Mechanics and Rock Engineering, 47(6), 22252238.

Shen, B., King, A. \& Guo, H. (2008). Displacement, stress and seismicity in roadway roofs during mining-induced failure. International Journal of Rock Mechanics and Mining Science, 45(5), 672-688.

Tang, Y. G. \& Kung, G. T. C. (2009). Application of nonlinear optimization technique to back analyses of deep excavation. Computers and Geotechnics, 36(1), 276-290.

Whittles, D. N., Lowndes, I. S., Kingman, S. W., Yates, C. \& Jobling, S. (2006). Influence of geotechnical factors on gas flow experienced in a UK longwall coal mine panel. International Journal of Rock Mechanics and Mining Science, 43(3), 369-387. Xie, H. P., Gao, F. \& Ju, Y. (2015). Research and development of rock mechanics in deep ground engineering. Chinese Journal of Rock Mechanics and Engineering, 34(11), 2161-2178. (in Chinese)

Yan, S., Bai, J. B., Wang, X. Y. \& Huo, L. J. (2013). An innovative approach for gateroad layout in highly gassy longwall top coal caving. International Journal of Rock Mechanics and Mining Science, 59, 33-41. 
Yang, S. Q., Chen, M., Jing, H. W., Chen, K. F. \& Meng, B. (2017). A case study on large deformation failure mechanism of deep soft rock roadway in Xin'An coal mine, China. Engineering Geology, 217, 89-101.

Yavuz, H. (2004). An estimation method for cover pressure reestablishment distance and pressure distribution in the goaf of longwall coal mines. International Journal of Rock Mechanics and Mining Science, 41(2), 193-205.

Yu, B., Zhang, Z. Y., Kuang, T. J. \& Liu, J. R. (2016). Stress Changes and Deformation Monitoring of Longwall Coal Pillars Located in Weak Ground. Rock Mechanics and Rock Engineering, 49(8), 3293-3305.

Zhang, S., Wang, X. F., Fan, G. W., Zhang, D. S. \& Cui, J. B. (2018). Pillar size optimization design of isolated island panel gobside entry driving in deep inclined coal seam-case study of Pingmei No. 6 coal seam. Journal of Geophysics and Engineering, 15(3), 816-828.

Zhang, Z. X., Xu, Y., Kulatilake, P. H. S. W. \& Huang, X. (2012). Physical model test and numerical analysis on the behavior of stratified rock masses during underground excavation. International Journal of Rock Mechanics and Mining Science, 49, 134147.

Zhu, W. S., Li, Y., Li, S. C., Wang, S. G. \& Zhang, Q. B. (2011). Quasi-three-dimensional physical model tests on a cavern complex under high in-situ stresses. International Journal of Rock Mechanics and Mining Science, 48(2), 199-209. 